\title{
Estimating larval fish ingestion rates: can laboratory derived values be reliably extrapolated to the wild?*
}

\author{
B. R. MacKenzie, W. C. Leggett, R. H. Peters \\ Department of Biology, McGill University, 1205 Ave. Dr. Penfield, Montréal, Québec, Canada H3A 1B1
}

\begin{abstract}
We used literature data to compare the relative influences of body size, water temperature food density and experimental method on laboratory derived estimates of the ingestion rates of marine fish larvae. We subsequently used these results to evaluate whether larval feeding rates in nature are likely to be food-limited. Larval dry weight, temperature and food density explained $85 \%$ of the variance in the laboratory derived ingestion rates of 11 species. After removing the effects of larval size and water temperature on ingestion rates, larval functional response was steepest at food densities $<\sim 185 \mathrm{\mu g} \mathrm{l}^{-1}$; beyond this level, ingestion rates were independent of food density. A comparison of the laboratory functional response with natural microzooplankton densities shows that (1) larvae are unlikely to feed at maximal rates in the sea; (2) larval feeding rates are most sensitive to changes in food abundance across the range of food densities that are most likely to occur in nature (median $=31 \mu \mathrm{g} \mathrm{l}^{-1}$; 90th percentile $=148 \mu \mathrm{g} \mathrm{l}^{-1} ; \mathrm{N}=46$ ). However, in situ ingestion rate estimates for 8 species of marine fish larvae indicate that these larvae fed at rates independent of food density and near-maximally, despite relatively low food densities. We conclude that this difference between in situ and laboratory estimates of ingestion rates as a function of prey density results primarily from the failure of most integrated census estimates of prey density to adequately represent the real contact rate of larvae with their prey and the failure of most laboratory experimental designs to incorporate relevant variables known to influence prey encounter rates and selection. Integrated measures of in situ prey abundance and most experimental designs fail to account for small-scale temporal and spatial patchiness in the distributions of larvae and their prey, for various aspects of larval behaviour, and for water-column turbulence.
\end{abstract}

\section{INTRODUCTION}

Laboratory ingestion rate studies involving individual species of larval fish have established that larvae display a sharp functional response at low food densities and that ingestion rates become satiated at much higher densities (Theilacker \& Dorsey 1980, Klumpp \& von Westernhagen 1986; also Holling 1959, Ivlev 1961). These laboratory-derived functional responses are often used to evaluate the extent to which naturally occurring food levels may influence larval survival and year-class strength in marine fish populations (e.g. Houde 1978, Wroblewski \& Richmann 1987, Anderson 1988).

However, extrapolation from laboratory estimates of food ingestion rates in this way could bias interpreta-

\footnotetext{
- Contribution to the program of GIROQ (Groupe interuniversitaire de recherches océanographiques du Québec)
}

tions of larval feeding ecology (Anderson 1988, Jenkins 1988 ) because they assume that laboratory derived functional responses are similar in form and magnitude to the functional responses of larvae in nature. This assumption may not be valid because experimental conditions themselves can influence laboratory ingestion and growth rates of larval fish (Houde 1977 , Theilacker \& Dorsey 1980, Hunter 1981) and other zooplankton (Peters \& Downing 1984, Delafontaine \& Leggett 1987). The relative importance of these experimentally induced biases in laboratory ingestion rates has not yet been quantified relative to the influences of larval size, water temperature and food density.

Moreover, no quantitative comparison of in situ larval feeding rates in response to local food densities has been attempted for wild larval populations. Hence the validity of the assumption that laboratory and natural functional responses are similar remains in doubt, as does the utility of the application of experimentally 
derived ingestion rates to wild populations (Rothschild \& Osborn 1988).

In this study we sought to identify the variables that influence the magnitude and form of ingestion rate responses to varying prey densities both in the laboratory and in the wild. We also used empirical models developed in the course of this analysis to evaluate whether ingestion rates of wild marine fish larvae are likely to be food-limited.

\section{METHODS}

Laboratory ingestion rates. Data collection and conventions: The data used in developing empirically based ingestion rate models were extracted from the literature relating to marine and estuarine species of fish larvae. We sought data on ingestion rate ( $I_{\text {; }}$ expressed as $\mu$ g dry weight of food ingested individual ${ }^{-1} \mathrm{~d}^{-1}$ ), larval dry weight $\left(\mathrm{W} ; \mu \mathrm{g}\right.$ individual $\left.{ }^{-1}\right)$, prey dry weight (PW; $\mu \mathrm{g}$ individual ${ }^{-1}$ ) and prey density (Food; numbers $1^{-1}$ or $\mu \mathrm{g}^{-1}$ ). We expressed body size and food densities in units of mass because these are known to represent energy flow better than units of length or numeric concentrations respectively (Houde 1978, Theilacker \& Dorsey 1980).

Sixty percent of all larvae contained in our data set were preserved in formalin before dry weight determinations were performed. Losses in dry weight are known to occur in larval fishes as a consequence of preservation but the magnitude of this loss has not been thoroughly evaluated (Delafontaine \& Leggett
1989, Giguère et al. 1989). Available estimates of preservation-induced dry weight loss range from 9 to $30 \%$ (Theilacker \& Dorsey 1980, Bailey 1982, Hay 1984). If reported dry weights had not been corrected for this preservation effect, we assumed a $20 \%$ dry weight loss, which is the midpoint of the published ranges (Theilacker \& Dorsey 1980, Bailey 1982, Hay 1984), before adjusting dry weight values accordingly.

In 7 of the 11 laboratory-based studies incorporated into our data set, prey dry weights were not reported. In these cases, we estimated prey dry weights from weight equivalents reported in the literature (Table 1). This allowed us to convert all numerical densities of prey components to equivalent dry weights in one of 3 ways: (1) in cases where the proportions of different prey items in the diet were reported $(\mathrm{N}=3$; Houde \& Schekter 1981, Theilacker 1987, Chesney 1989), we calculated the total dry weight of all food offered in each experimental treatment as follows:

$$
\text { Food }=\sum_{i=1}^{n}\left(P_{i} \cdot P W_{i} \quad D\right)
$$

where Food $=$ food density $\left(\mu \mathrm{g} \mathrm{l}^{-1}\right) ; \mathrm{P}_{\mathrm{i}}=$ numerical proportion (range 0.0 to 1.0) of component $i$ in the total prey population; $\mathrm{PW}_{\mathrm{i}}=$ dry weight equivalent of 1 prey item of component $i ; \mathrm{D}=$ total prey population density (number $\mathrm{l}^{-1}$ ), and $\mathrm{n}=$ number of prey components in the prey population; (2) in cases where the relative proportions of individual prey components were not reported $(N=1$ : Monteleone \& Peterson 1986), we estimated the dry weight biomass of food with Eq. (1) by assuming that the diet was comprised of equal

Table 1. Conventions, extracted from the literature, used to estimate the influence of food density on larval fish ingestion rates. Data sources listed alphabetically below table

\begin{tabular}{|c|c|}
\hline Convention & Reference \\
\hline Preserved larval fish dry weight $=0.8 \times$ unpreserved larval fish dry weight & $5,7,8,16$ \\
\hline Preserved zooplankton dry weight $=0.6 \times$ unpreserved zooplankton dry weight & 7,18 \\
\hline Carbon mass $=0.4 \times$ dry mass (zooplankton) & 15 \\
\hline Carbon mass $=0.55 \times$ dry mass (Artemia nauplii) & 14 \\
\hline Dry mass $=0.2 \times$ wet mass (fish larvae) & 12 \\
\hline Specific gravity of zooplankton $=1 \mathrm{~g} \mathrm{~cm}^{-3}$ & 11 \\
\hline$\%$ ash $=0.11 \times$ dry weight & 1 \\
\hline Acartia tonsa nauplius $=0.26 \mu \mathrm{g}$ & 6 \\
\hline Artemia nauplius $=1.85 \mu \mathrm{g}$ & 2 \\
\hline Brachionus (mixed sizes) $=0.16 \mu \mathrm{g}$ & 17 \\
\hline Calanus finmarchicus (nauplius) $=1.5 \mathrm{~kg}$ & 4 \\
\hline Eurytemora affinis (nauplius) $=0.28 \mu \mathrm{g}$ & 3,10 \\
\hline E. affinis (copepodite) $=2.2 \mu \mathrm{g}$ & 3 \\
\hline E. affinis (adult) $=10.4 \mu \mathrm{g}$ (April-May in Chesapeake estuary) & 9 \\
\hline Pseudocalanus (nauplius) $=0.26 \mu \mathrm{g}$ & 13 \\
\hline \multicolumn{2}{|c|}{$\begin{array}{l}\text { 1, Båmstedt (1986); 2, Benijts et al. (1975); 3, Burkhill \& Kendall (1982; see also Chesney 1989); 4, Davis (1984); 5, Delafontaine } \\
\text { \& Leggett (1989); 6, Durbin \& Durbin (1981); 7, Giguère et al. (1989); 8, Hay (1984); 9, Heinle \& Fremer (1975; see aiso Chesney } \\
\text { 1989); 10, Houde \& Schekter (1981; see also Chesney 1989); 11, MacCauley (1984); 12, McGurk (1986); 13, Monteleone \& } \\
\text { Peterson (1986); 14, Oppenheimer \& Moreira (1980); 15, Peters (1983); 16, Theilacker \& Dorsey (1980); 17, Theilacker \& } \\
\text { McMaster (1971); 18, Vidal \& Smith (1986) }\end{array}$} \\
\hline
\end{tabular}


proportions of all prey; (3) in cases where only 1 size of prey was offered per experimental treatment $(\mathrm{N}=7$ ), we multiplied the numerical density of prey by the dry weight equivalent of an individual prey comprising the diet.

All 11 studies used in our analysis reported ingestion rate estimates for larvae of several sizes. To minimize potential bias caused by over-representation of 1 or 2 species whose ingestion rates were measured several times in 1 study and at a narrow range of experimental conditions, we restricted our data to the lower and upper limits, and midpoint, of the reported size range of larvae used in each combination of experimental conditions.

All ingestion rate estimates were standardized to a $12 \mathrm{~h}$ feeding period. We adopted this convention because larval fish are visual feeders (Hunter 1981, Blaxter 1988).

To evaluate the potential effects of methodological factors on laboratory estimates of ingestion rate, we included in our data set water temperature, experimental container volume, larval density (numbers $1^{-1}$ ), and prey type (Brachionus and/or Artemia, or wild zooplankton). The results of earlier studies of ingestion rates of larval fish and other zooplankton (e.g. Rosenthal \& Hempel 1970, Houde 1977, Barahona-Fernandes \& Conan 1981, Peters \& Downing 1984, Delafontaine \& Leggett 1987) suggested that these variables can be important contributors to observed variation in measured ingestion rates. Several other variables that are also believed to influence ingestion rates (e.g. turbulence, light intensity, turbidity; Chesney 1989) were not evaluated because they were reported too infrequently to be incorporated in the analyses.

Statistical techniques: All data were expressed in standard units as detailed above. Ingestion rates, larval and prey sizes, larval and food densities were logarithmically-transformed (base 10) prior to regression analysis to linearize allometric relationships and stabilize the variance in our data set (Peters \& Downing 1984). In our analysis we intentionally excluded interaction and higher order terms to retain simplicity and to reduce the likelihood of fitting the model to outliers (Peters \& Downing 1984), even though this exclusion may reduce the amount of variance explained.

We used analysis of covariance (Zar 1974) to distinguish the possible effect of different prey types (e.g. Rosenthal \& Hempel 1970, Vu 1983). We coded Artemia nauplii or Brachionus as 0 and wild zooplankton native to the larval habitat, whether collected from the sea or cultured in the laboratory, as 1.

Model construction: Body size strongly influences ingestion rates in a wide variety of animals (Peters 1983) and influences many other life-history traits among larval fish (Miller et al. 1988). We first examined the effect of larval size on ingestion rates before considering other variables. We then used stepwise regression and scatterplots to evaluate the influence of the remaining variables on residual variation about the allometric model, and all subsequent models. The criterion for variable selection and retention was set at $p<0.05$. All computations were performed with SAS 6.0 (PC version; SAS 1985a, b) and Systat 4.0 (Wilkinson 1988)

Larval feeding ecology in nature. Natural microzooplankton densities: We used the laboratory based functional response models we developed to investigate the likelihood that natural food densities permit wild larvae to feed at maximal rates. For this analysis, we compiled literature estimates of microzooplankton abundance for a variety of marine environments (Table 2).

In developing this data set we used only microzooplankton abundance estimates derived in studies that employed mesh sizes $<200 \mu \mathrm{m}$. This was done because early stage larvae generally consume prey smaller than this size (Theilacker \& Dorsey 1980, Frank 1988). In some studies zooplankton samples were size-fractionated prior to weighing. In these cases we used only those data which related to size classes which closely corresponded to the $<200 \mu \mathrm{m}$ component. This reduced, but did not eliminate, the possible effect of contamination by larger zooplankton on estimates of larval prey abundance.

We recorded the average and maximum (Owen 1989) prey density in each study. Many data were extracted directly from figures and tables. In some cases, authors reported prey densities as ranges or averages. In these cases we used range midpoints or averages as representative densities for the areas in question. In cases where distinct habitats were sampled (e.g. within and beyond an upwelling region), we grouped data accordingly in order to accurately reflect these different hydrographic regimes. In cases where the seasonal occurrence of fish larvae was known for a given area or habitat, we used only zooplankton densities corresponding to that interval.

Ingestion rates of wild larvae: To examine how ingestion rates of wild larvae were related to food density, we gathered from the literature ingestion rates for wild and enclosure-reared larvae and compared these as a group with those predicted by our laboratory-based model. Ingestion rates of wild larvae were estimated using either gut content analyses of fieldcollected specimens combined with a corresponding species-specific laboratory estimate of digestion rate ( $\mathrm{N}$ = 5; Dagg et al. 1984, Ellertsen et al. 1984), or were calculated from growth rate and in situ temperatures $(N=31$; see Checkley 1984). In compiling this data base, we only included data from field studies in which 
Table 2. Microzooplankton densities at 46 marine and estuarine sites worldwide. Densities in the table are listed as means; maxima

\begin{tabular}{|c|c|c|c|}
\hline Site & Size or taxa & $\begin{array}{l}\text { Prey density } \\
\left(\mu \mathrm{g} \mathrm{l}^{-1}\right)\end{array}$ & Reference \\
\hline \multicolumn{4}{|l|}{ Shelves and bays } \\
\hline Baltic Sea & $>90 \mu \mathrm{m}$ & $\begin{array}{l}148 ; 240 \\
377 ; 692\end{array}$ & $\begin{array}{l}\text { Kahru et al. (1984), Table 1; Aug } 1982 . \\
\text { (fresh and salty sides of front respectively) }\end{array}$ \\
\hline Bering Sea (southeast region) & Nauplii of Pseudocalanus & $5 ; 12$ & Dagg et al. (1984), Fig. 5; May 1981 \\
\hline Biscayne Bay, Florida, USA & $>20 \mu \mathrm{m}$ & $70 ; 88$ & $\begin{array}{l}\text { Leak \& Houde (1987), Table } 7 \text {; assume } 1 \\
\text { plankter }=0.33 \mu \mathrm{g} \text { (Houde \& Schekter } \\
\text { 1981) }\end{array}$ \\
\hline Block Island Sound, R.I., USA & $>153 \mu \mathrm{m}$ & $33 ; 67$ & Deevey (1952), Fig. 4; May-Sep 1949 \\
\hline Bryants Cove, Newfoundland & $90-130 \mu \mathrm{m}$ & $18 ; 201$ & $\begin{array}{l}\text { Taggart \& Leggett (1987), Table 1; } \\
\text { Jun-Aug 1981-1983 }\end{array}$ \\
\hline Buchan front, Scotland & $30-200 \mu \mathrm{m}$ & $9 ; 15$ & $\begin{array}{l}\text { Kiørboe \& Johansen (1986), Fig. 5; } \\
\text { Sep } 1984\end{array}$ \\
\hline Buchan front, Scotland & $30-200 \mu \mathrm{m}$ copepods & $10: 15$ & Kiorboe et al. (1988), Fig. 5; Sep-Oct 1985 \\
\hline $\begin{array}{l}\text { California: San Diego to Isla } \\
\text { Guadeloupe }\end{array}$ & $35-202 \mu \mathrm{m}$ & $2.4 ; 2.6$ & $\begin{array}{l}\text { Beers \& Stewart (1969), Table 5; Feb } 1967 . \\
\text { Oceanic stations }\end{array}$ \\
\hline California Current transect & $35-200 \mathrm{~mm}$ & $1.3 ; 3.5$ & $\begin{array}{l}\text { Beers \& Stewart (1967), Table 4; Dec 9-16, } \\
\text { 1965. Oceanic stations }\end{array}$ \\
\hline $\begin{array}{l}\text { Chesapeake Bay } \\
\text { Patuxent R., USA }\end{array}$ & $\begin{array}{l}\text { A. tonsa } \\
>80 u \mathrm{~m}\end{array}$ & $177 ; 349$ & Heinle (1966), Table 5; Jul-Aug 1964 \\
\hline $\begin{array}{l}\text { Chesapeake Bay, North Inlet, } \\
\text { South Carolina, USA }\end{array}$ & $>153 \mu \mathrm{m}$ & $16 ; 233$ & $\begin{array}{l}\text { Lonsdale \& Coull (1977), Fig. } 2 \text {; } \\
\text { Jan 1974-Aug } 1975\end{array}$ \\
\hline English Channel & $80-200 \mu \mathrm{m}$ & $31: 37$ & Holligan et al. (1984), Table 4; Jul 29, 1981 \\
\hline $\begin{array}{l}\text { Georges Bank } \\
\text { well-mixed } \\
\text { stratified } \\
\text { stratified }\end{array}$ & $>64 \mu \mathrm{m}$ & $\begin{array}{l}17 ; 25 \\
59 ; 117 \\
90 ; 278\end{array}$ & $\begin{array}{l}\text { Buckley \& Lough (1987). Table 2; } \\
\text { May } 1983\end{array}$ \\
\hline Kiel Bight, F.R. Germany & $20-200 \mu \mathrm{m}$ & $10 ; 21$ & Smetacek (1981) Fig. 6; May-Aug 1973 \\
\hline $\begin{array}{l}\text { Lancaster Sound, eastern } \\
\text { Canadian Arctic (74 N) }\end{array}$ & $35-200 \mu \mathrm{m}$ & $20: 122$ & $\begin{array}{l}\text { Paranjape (1988), Fig 5; Aug } 1980 . \\
\text { Upper } 40 \mathrm{~m}\end{array}$ \\
\hline Lindăspollene, Norway & $>75 \mu \mathrm{m}$ & $26 ; 45$ & $\begin{array}{l}\text { Aksnes \& Magnesen (1988), Figs. } 8 \& 9 A_{i} \\
\text { Jun } 1981\end{array}$ \\
\hline Lofoten Islands, Norway & $>90 \mu \mathrm{m}$ & $14 ; 36$ & $\begin{array}{l}\text { Ellertsen et al. (1984). Fig. 6: May } \\
\text { 1980-1982. Copepod nauplii (mainly } \\
\text { Calanus finmarchicus) }\end{array}$ \\
\hline Long Island So., New York, USA & $>64 \mu \mathrm{m}$ & $11 ; 14$ & $\begin{array}{l}\text { Peterson \& Ausubel (1984), Fig. 5; May } \\
\text { 19-Jun 6, 1982. Nauplii of Acartia tonsa } \\
\text { and Pseudocalanus sp. }\end{array}$ \\
\hline Long Island So., New York, USA & $>64 \mu \mathrm{m}$ & $\begin{array}{l}14 ; 23 \\
100 ; 200\end{array}$ & $\begin{array}{l}\text { Monteleone \& Peterson (1986), Table 5; } \\
\text { Mar (copepod nauplii) and Apr } \\
\text { (copepodites) } 1983\end{array}$ \\
\hline Masfjorden, Norway & $>180 \mu \mathrm{m}$ & $27: 49$ & $\begin{array}{l}\text { Äksnes et al. (1989), Fig. 2i Jun and Oct } \\
1985\end{array}$ \\
\hline $\begin{array}{l}\text { Narragansett Bay, } \\
\text { Rhode Island }\end{array}$ & $60-150 \mu \mathrm{m}$ & $90 ; 220$ & $\begin{array}{l}\text { Durbin \& Durbin (1981), Fig. 6; May=Aug } \\
1976\end{array}$ \\
\hline Newport River Estuary, USA. & $>160 \mu \mathrm{m}$ & $40 ; 72$ & $\begin{array}{l}\text { Thayer et al. (1974), Fig. 2; Feb-A.pr } \\
\text { 1970-1972 }\end{array}$ \\
\hline $\begin{array}{l}\text { Northumberland coast, } \\
\text { North Sea }\end{array}$ & $>44 \mu \mathrm{m}$ & $37 ; 62$ & $\begin{array}{l}\text { Evans (1977); Fransz et al. (1984); May, Jul. } \\
\text { and Sep 1971-1972 }\end{array}$ \\
\hline $\begin{array}{l}\text { Northwest Africa (beyond } \\
\text { upwelling zone) }\end{array}$ & $102-505 \mu \mathrm{m}$ & $11 ; 25$ & $\begin{array}{l}\text { Blackburn \& Nellen (1976), Figs. 2-4; } \\
\text { March-May } 1974\end{array}$ \\
\hline $\begin{array}{l}\text { Nova Scotian Shelf (transect } \\
\text { southeast from Halifax, } \\
\text { Canada) }\end{array}$ & $>200 \mu \mathrm{m}$ & $8 ; 18$ & Paranjape et al. (1985), Table 1; Mar 1980 \\
\hline
\end{tabular}


Table 2 (continued)

\begin{tabular}{|c|c|c|c|}
\hline Site & Size or taxa & $\begin{array}{l}\text { Prey density } \\
\left(\mu \mathrm{g} \mathrm{l}^{-1}\right)\end{array}$ & Reference \\
\hline Onslow Bay, N. Carolina, USA & $>110 \mu \mathrm{m}$ & $57 ; 103$ & $\begin{array}{l}\text { Paffenhöfer (1980), Table 5; Jul-Aug } 1976 . \\
\text { Surface, non-upwelled water mass }\end{array}$ \\
\hline $\begin{array}{l}\text { Oyster Grounds (south-central } \\
\text { North Sea) }\end{array}$ & $>50 \mu \mathrm{m}$ & $43 ; 56$ & Fransz et al. (1984); May, Jun and Sep \\
\hline Peru (beyond upwelling zone) & $>102 \mu \mathrm{m}$ & 9 & Smith et al. (1981), Fig. 4 ; Apr 1976 \\
\hline $\begin{array}{l}\text { St. Georges Bay, Nova Scotia, } \\
\text { Canada }\end{array}$ & $25-250 \mu \mathrm{m}$ & $50 ; 70$ & $\begin{array}{l}\text { Hargrave et al. (1985), Fig. 6; May-Sep. } \\
1977\end{array}$ \\
\hline Southern Bight, North Sea & $>50 \mu \mathrm{m}$ & $\begin{array}{l}97 ; 197 \\
56 ; 67\end{array}$ & $\begin{array}{l}\text { Fransz et al. (1984), Table 5; } 1973-1975 \text {. } \\
\text { Coastal and offshore stations respectively }\end{array}$ \\
\hline $\begin{array}{l}\text { Southwest Nova Scotia, } \\
\text { Canada }\end{array}$ & $80-153 \mu \mathrm{m}$ & $\begin{array}{l}33 \\
8\end{array}$ & $\begin{array}{l}\text { Frank (1988), Fig. 4; May } 1985 \text { and } 1986 \\
\text { respectively. Samples collected byond } \\
\text { upwelling zone described by Garrett \& } \\
\text { Loucks (1976) }\end{array}$ \\
\hline Tampa Bay, Florida, USA & $>74 \mu \mathrm{m}$ & $41 ; 54$ & Hopkins (1977), Table 3; May-Aug 1970 \\
\hline Tasman Bay, New Zealand & $>60 \mu \mathrm{m}$ & $233 ; 333$ & $\begin{array}{l}\text { MacKenzie \& Gillespie (1986); Oct-Mar } \\
\text { 1982-1984 }\end{array}$ \\
\hline $\begin{array}{l}\text { Tikehau atoll, Tuamotu } \\
\text { archipelago }\end{array}$ & $35-200 \mu \mathrm{m}$ & $14 ; 40$ & $\begin{array}{l}\text { Leborgne et al. (1989); April 1986; Table } 1 \\
\text { and Fig. } 6\end{array}$ \\
\hline Wadden Sea (Sylt channel) & $>76 \mu \mathrm{m}$ & $99 ; 149$ & $\begin{array}{l}\text { Martens (1980); May, Jun and Sep. See } \\
\text { Fransz et al. (1984) }\end{array}$ \\
\hline \multicolumn{4}{|l|}{ Upwelling zones } \\
\hline $\begin{array}{l}\text { Benguela Current, St. Helena } \\
\text { Bay }\end{array}$ & $<500 \mu \mathrm{m}$ & $357 ; 724$ & $\begin{array}{l}\text { James \& Findlay (1989), Table 4; Apr-May, } \\
1985\end{array}$ \\
\hline $\begin{array}{l}\text { California: San Diego to Isla } \\
\text { Guadeloupe }\end{array}$ & $35-200 \mu \mathrm{m}$ & $3.5 ; 4.5$ & $\begin{array}{l}\text { Beers \& Stewart (1969), Table 5; Feb } 1967 . \\
\text { Slope stations }\end{array}$ \\
\hline $\begin{array}{l}\text { California Current } \\
\text { transect }\end{array}$ & $35-200 \mu \mathrm{m}$ & $3.3 ; 4.6$ & $\begin{array}{l}\text { Beers \& Stewart (1967), Table 4; Dec 9-16, } \\
\text { 1965. Inshore stations }\end{array}$ \\
\hline $\begin{array}{l}\text { South Taranaki Bight, } \\
\text { New Zealand }\end{array}$ & $>100 \mu \mathrm{m}$ & $12 ; 25$ & $\begin{array}{l}\text { Foster \& Battaerd (1985), Fig, 3; Feb } 1981 \\
\text { (16-82 km from coast) }\end{array}$ \\
\hline Cape Kahurangi, New Zealand & $>100 \mu \mathrm{m}$ & $25 ;>40$ & $\begin{array}{l}\text { James \& Wilkinson (1988), Fig. 2; } \\
\text { Mar-Apr } 1983\end{array}$ \\
\hline Northwest Africa & $102-505 \mu \mathrm{m}$ & $132 ; 268$ & $\begin{array}{l}\text { Blackburn \& Nellen (1976), Figs. 2-4; } \\
\text { Mar-May } 1974\end{array}$ \\
\hline Onslow Bay, N. Carolina, USA & $>110 \mu \mathrm{m}$ & $97 ; 181$ & $\begin{array}{l}\text { Paffenhöfer (1980), Table 5; Jul-Aug } 1976 \\
\text { (intrusion, upwelled water mass) }\end{array}$ \\
\hline Oregon, USA & $>120 \mu \mathrm{m}$ & $125 ; 200$ & $\begin{array}{l}\text { Peterson et al. (1979), Jul-Sep 1973; } \\
\text { Aug } 1974\end{array}$ \\
\hline Peru; $15^{\circ} \mathrm{S}$ & $>102 \mu \mathrm{m}$ & $17 ; 26$ & Smith et al. (1981), Fig. 4; Apr 1976 \\
\hline Peru; $10^{\circ} \mathrm{S}$ & $102-505 \mu \mathrm{m}$ & $31 ; 62$ & Whitledge (1981); Table 5; Apr 1977 \\
\hline Peru; $15^{\circ} \mathrm{S}$ & $102-505 \mu \mathrm{m}$ & $17 ; 24$ & Whitledge (1981); Table 5; Apr 1977 \\
\hline $\begin{array}{l}\text { South Taranaki Bight. } \\
\text { New Zealand }\end{array}$ & $>100 \mu \mathrm{m}$ & $25_{i}>50$ & $\begin{array}{l}\text { James \& Wilkinson (1988), Mar-Apr 1983; } \\
\text { Fig. } 3\end{array}$ \\
\hline $\begin{array}{l}\text { Southwest Nova Scotia, } \\
\text { Canada }\end{array}$ & $80-153 \mu \mathrm{m}$ & $\begin{array}{l}167 \\
58\end{array}$ & $\begin{array}{l}\text { Frank (1988), Fig. 4; May (1985, 1986). } \\
\text { Samples collected within upwelling zone } \\
\text { described by Garrett \& Loucks (1976) }\end{array}$ \\
\hline
\end{tabular}

larvae and their prey were sampled simultaneously during a particular research survey. These estimated rates of ingestion and accompanying food densities are considered to represent average growth rates and food levels for larvae in the given geographic region during the time interval when plankton samples were being collected (Table 3).

\section{RESULTS AND DISCUSSION}

\section{Laboratory ingestion rate models}

The best single predictor of laboratory ingestion rates was body size (Model 1; Table 4). Size was a powerful cross-species indicator of ingestion rates despite large 
differences in temperature, food density and other laboratory procedures (Table 5). Clearly, larval size effectively integrates a wide range of ecological and life-history traits in fish larvae (see also Peters 1983, Miller et al. 1988).

Physiological rates in larval, juvenile and adult fishes are either allometrically (Winberg 1956, Rombough 1988) or isometrically (Giguère et al. 1988, Rombough 1988 ) related to body size. The regression coefficients for body size in our laboratory models varied from 0.843 to 0.990 but the variance about these coefficients (Table 4) prevented us from distinguishing whether ingestion rates are allometrically or isometrically related to body size.

Temperature was the major contributor to explained variance in ingestion rates once the effect of body size was removed (Model 2). The regression coefficient for the temperature term in Model 2 equates to a $Q_{10}$ value of $2.3(95 \%$ confidence limits $=1.6$ and 3.2$)$. The similarity of $Q_{10}$ estimated from our data to that abtained in other general physiology studies (2 to 3 ; Prosser 1973) suggests that laboratory ingestion rates of larval fish respond to temperature in a manner similar to physiological rates in a wide variety of other organisms. Consequently larvae that hatch in low latitude areas can be expected to have higher ingestion rates and higher growth rates (see also Houde 1989), than those which hatch in boreal regions. Because $Q_{10}$ values vary with temperature (McLaren 1963), our estimate is most appropriate for those temperatures near the mean in our data set $\left(18.7^{\circ} \mathrm{C}\right)$.

A scatterplot of ingestion rates detrended for the effects of larval size and temperature using Model 2 qualitatively indicates that ingestion rates plateau at a

Table 3. Data sources used to estimate natural ingestion rates from gut content analysis or larval growth rates

\begin{tabular}{|c|c|c|}
\hline Reference & Species & Data and comments \\
\hline $\begin{array}{l}\text { Buckley \& Lough } \\
\text { (1987) }\end{array}$ & Gadus morhua & $\begin{array}{l}\left.\text { Growth rate and } \mathrm{T}\left(9^{\circ} \mathrm{C}\right) \text { available in Table } 7 . \mathrm{W}=2950 \mu \mathrm{g} \text { (Table } 5\right) \text { and } \\
\left.\text { Food }=17 \mu \mathrm{gl}^{-1} \text { (Fig. } 4\right)\end{array}$ \\
\hline $\begin{array}{l}\text { Buckley \& Lough } \\
(1987)\end{array}$ & $\begin{array}{l}\text { Melanogrammus } \\
\text { aeglefinus }\end{array}$ & $\begin{array}{l}\mathrm{T}=6 \text { and } 9^{\circ} \mathrm{C}(\text { Table } 7) ; \mathrm{W}=790-860 \mu \mathrm{g}(\text { Table } 4) . \text { Food }=15-133 \mu \mathrm{g} \mathrm{l}^{-1} \\
\text { (Fig. } 4 \text { ) }\end{array}$ \\
\hline $\begin{array}{l}\text { Dagg et al. } \\
(1984)\end{array}$ & Theragra chalcogramma & $\begin{array}{l}\text { Food density was } 15 \text { Pseudocalanus nauplii } \mathrm{l}^{-1} \text { (average density at } 20 \mathrm{~m} \text {; } \\
\text { Fig. 5). Larval lengths (5.2 mm) were converted to dry weight using } \\
\text { length-dry weight relation (Bailey \& Stehr } 1986 \text { ). } \mathrm{T}=4.5^{\circ} \mathrm{C}\end{array}$ \\
\hline $\begin{array}{l}\text { Ellertsen et al. } \\
(1984)\end{array}$ & Gadus morhua & $\begin{array}{l}\mathrm{T}=4.5^{\circ} \mathrm{C} \text { (Figs. } 3 \& 8 \text { ). Dominant prey of diet was Calanus finmarchicus } \\
\text { nauplii; densities at } 4 \text { sites were } 21,6,6 \text { and } 4 \text { individuals } l^{-1} \text { (Fig. } 6 \text { ). Gut } \\
\text { clearance time for larval cod at } 5^{\circ} \mathrm{C} \text { is estimated to be } 1.5 \mathrm{~h} \text { (Tilseth \& } \\
\text { Ellertsen } 1984 \text { ) }\end{array}$ \\
\hline $\begin{array}{l}\text { Frank \& Leggett } \\
\text { (1982a) }\end{array}$ & Mallotus villosus & $\begin{array}{l}\text { In situ enclosure experiments. Growth rates and food densities in Fig. } 8 \text {. } \\
\text { Assumed average size at hatch was } 4.8 \mathrm{~mm} \text { SL (Fortier \& Leggett } 1982_{i} \\
\text { Table 3). Lengths converted to dry weights using length-weight relation- } \\
\text { ship (Moksness } 1982 \text { ). Specific growth rates (dry weight basis) were used } \\
\text { to estimate ingestion rates at midpoint of experiment }\left(3.5 \mathrm{~d} \text { ). } \mathrm{T}=6.5^{\circ} \mathrm{C}\right.\end{array}$ \\
\hline $\begin{array}{l}\text { Gamble \& Houde } \\
\text { (1984) }\end{array}$ & Gadus morhua & $\begin{array}{l}\text { In situ enclosure experiment. Average } \mathrm{T} \text { and photoperiod were } 8^{\circ} \mathrm{C} \text { and } \\
17 \mathrm{~h} \text {. Average densities of copepod nauplii were } 21.5 \text { (range }=6-40 \text { ) and } \\
23 \mathrm{I}^{-1} ; 80 \% \text { of all nauplii were Pseudocalanus elongatus, which domi- } \\
\text { nated larval diets }\end{array}$ \\
\hline $\begin{array}{l}\text { Leak \& Houde } \\
\text { (1987) }\end{array}$ & Anchoa mitchilli & $\begin{array}{l}\text { Larval sizes at age } 10 \mathrm{~d} \text { were calculated from growth rate equations (Table } \\
\text { 5). Mean } T \text { and microzooplankton densities in Tables } 1 \& 5 \text {. Average } \\
\text { weight of an individual particle comprising mixed Florida microzooplank- } \\
\text { ton was } 0.33 \mu \mathrm{g} \text { (Houde \& Schekter 1981) }\end{array}$ \\
\hline $\begin{array}{l}\text { Monteleone \& } \\
\text { Peterson (1986) }\end{array}$ & Ammodytes americanus & $\begin{array}{l}\text { Average Food }=60.8 \mu \mathrm{g} \mathrm{I}^{-1} \text { for Mar-Apr } 1983(\text { Tables } 2 \& 5) \text {. Average } \mathrm{T} \\
\text { and photoperiod were } 4.5^{\circ} \mathrm{C} \text { and } 11 . \text { Specific growth rate }=4.0 \% \mathrm{~d}^{-1} \text { in } \\
\text { nature. Average } \mathrm{W} \text { in } \mathrm{Mar}=992 \mu \mathrm{g}(\text { Table } 3 \mathrm{~A})\end{array}$ \\
\hline $\begin{array}{l}\text { Munk et al. } \\
\text { (1986) }\end{array}$ & Clupea harengus & $\begin{array}{l}\text { Lengths converted to dry weights using fall } 1978 \text { relationship given by } \\
\text { Gamble et al. (1985; Table } 8 \text { ). } \mathrm{T}=12^{\circ} \mathrm{C} \text { (Richardson et al. 1986; Fig. 5A). } \\
\text { Food }=6.2 \mu \mathrm{g} \mathrm{l}^{-1} \text { (Kiørboe \& Johansen } 1986 ; \text { p. } 50 \text { ) }\end{array}$ \\
\hline $\begin{array}{l}\text { Peterson \& Ausubel } \\
\text { (1984) }\end{array}$ & Scomber scombrus & $\begin{array}{l}\text { W and growth rates in Table } 3 \text {. Larvae collected mostly in upper } 10 \mathrm{~m} \text { of } \\
\text { water column. Authors considered Acartia tonsa and Pseudocalanus nau- } \\
\text { plii as larval prey. Densities of these prey are presented in Table } 2 \text { and } \\
\text { Fig. } 5 \text {. Assume average } T \text { where larvae were most abundant is } \approx 14^{\circ} \mathrm{C} \text {; } \\
\text { photoperiod }=15 \mathrm{~h}\end{array}$ \\
\hline
\end{tabular}


Table 4. Models describing ingestion rates for laboratory (Models 1 to $4 ; \mathrm{n}=109$ with 11 species) and wild (Model $5 ; \mathrm{n}=36$ with 8 species) populations of larval fish. For Model 3, 'Res' refers to residual ingestion rates which have been calculated as the difference between observed ingestion rates and those predicted using larval size and experimental temperature as inputs to Model 2. For Models 3 and 4, 'Crit' refers to the critical food density beyond which ingestion rates are independent of food density. Thus Model 3 simplifies to Res $=0.250$ when food densities exceed $173 \mu \mathrm{g} \mathrm{l^{-1 }}$ and Model 4 simplifies to Log I $=0.843 \log \mathrm{W}+$ $0.038 \mathrm{~T}-0.622$ when food densities exceed $185 \mu \mathrm{g} \mathrm{l}^{-1} \mathrm{SE}=$ standard error of parameter estimate; $\mathrm{x}_{1}=$ independent variable

\begin{tabular}{|c|c|c|c|c|c|c|}
\hline \multicolumn{3}{|c|}{ Model } & $\mathrm{SE}$ & Range of $x_{1}$ & $\mathrm{R}^{2}$ & Data sources \\
\hline \multicolumn{3}{|c|}{$\begin{aligned} \text { 1. } \log I= & 0.881 \log W \\
& -0.270\end{aligned}$} & $\begin{array}{l}0.077 \\
0.170\end{array}$ & $0.929-3.466$ & 0.56 & $\begin{array}{l}2,7,8,9,10,11,13 \\
16,17,18,19\end{array}$ \\
\hline \multicolumn{3}{|c|}{ 2. $\begin{aligned} \log I= & 0.990 \log W \\
& +0.036 \mathrm{~T} \\
& -1.170\end{aligned}$} & $\begin{array}{l}0.070 \\
0.007 \\
0.224\end{array}$ & $\begin{array}{c}0.929-3.466 \\
2-29\end{array}$ & 0.65 & $\begin{array}{l}2,7,8,9,10,11,13 \\
16,17,18,19\end{array}$ \\
\hline \multicolumn{3}{|c|}{ 3. $\begin{aligned} \text { Res }= & 0.869 \log \text { Food } \\
& -1.696\end{aligned}$} & $\begin{array}{l}0.107 \\
0.181\end{array}$ & $0.860-4.944$ & 0.55 & $\begin{array}{l}2,7,8,9,10,11,13 \\
16,17,18,19\end{array}$ \\
\hline \multicolumn{3}{|c|}{$\begin{aligned} \text { Crit } & =\log (173) \\
& =2.239\end{aligned}$} & 0.105 & & & \\
\hline & $\log I=$ & $\begin{aligned}= & 0.843 \log W \\
& +0.038 \mathrm{~T} \\
& +0.918 \log \text { Food } \\
& -2.704\end{aligned}$ & $\begin{array}{l}0.047 \\
0.004 \\
0.077 \\
0.192\end{array}$ & $\begin{array}{c}0.929-3.466 \\
2-29 \\
0.860-4.944\end{array}$ & 0.85 & $\begin{array}{l}2,7,8,9,10,11,13 \\
16,17,18,19\end{array}$ \\
\hline & $\begin{aligned} \text { Crit } & = \\
& =\end{aligned}$ & $\begin{array}{l}=\log (185) \\
=2.268\end{array}$ & 0.034 & & & \\
\hline 5. & $\log I=$ & $\begin{aligned}= & 1.162 \log W \\
& +0.029 \mathrm{~T} \\
& -1.343\end{aligned}$ & $\begin{array}{l}0.077 \\
0.007\end{array}$ & $\begin{array}{c}1.373-3.470 \\
4-31\end{array}$ & 0.89 & $\begin{array}{l}1,3,4,5,6,12,14, \\
15\end{array}$ \\
\hline \multicolumn{7}{|c|}{$\begin{array}{l}\text { 1, Buckley \& Lough (1987); 2, Chesney (1989); 3, Daggetal. (1984); 4, Ellertsen et al. (1984); 5, Frank \& Leggett (1982a); 6, Gamble } 8 \\
\text { Houde (1984); 7, Govoni et al. (1982); 8, Houde \& Schekter (1981); 9. Hunter \& Kimbrell (1980); 10, Klumpp \& von Westernhager } \\
\text { (1986); 11, Kuronuma \& Fukusho (1984); 12, Leak \& Houde (1987); 13, Monteleone \& Peterson (1986); 14, Munk et al. (1986) } \\
\text { 15, Peterson \& Ausubel (1984); 16. Stepien (1976); 17. Theilacker (1987); 18, Tucker (1989); 19, Werner \& Blaxter (1981) }\end{array}$} \\
\hline
\end{tabular}

Table 5. Means and ranges of variables assessed for their influence on larval fish ingestion rates determined in the laboratory. $\mathrm{W}=$ larval dry weight; Food $=$ food density; $\mathrm{D}=$ fish density; $\mathrm{T}=$ temperature $_{i} \mathrm{~V}=$ tank volume; $\mathrm{PW}=$ prey dry weight; $\mathrm{PT}=$ type of prey offered in ingestion rate experiments

\begin{tabular}{|c|c|c|c|}
\hline Variable & Mean & Range & $\mathrm{N}$ \\
\hline $\log W(\mu \mathrm{g})$ & 2.122 & $0.929-3.466$ & 109 \\
\hline $\log$ Food $\left(\mu \mathrm{gl}^{-1}\right)$ & 2.496 & $0.860-4.944$ & 109 \\
\hline $\log \mathrm{D}\left(\mathrm{Nl}^{-1}\right)$ & 0.513 & $-1.000-1.824$ & 70 \\
\hline $\mathrm{T}\left({ }^{\circ} \mathrm{C}\right)$ & 18.7 & $2-29$ & 109 \\
\hline$V(l)$ & 20.3 & $0.6-75$ & 88 \\
\hline $\log$ PW $(\mu g)$ & -0.417 & $-0.921-0.322$ & 109 \\
\hline $\mathrm{PT}$ & - & $\begin{array}{c}0 \text { if Artemia or } \\
\text { Brachionus }(\mathrm{N}=56) \text {; } \\
1 \text { if wild zooplankton } \\
\quad(\mathrm{N}=53)\end{array}$ & 109 \\
\hline
\end{tabular}

food density of approximately 150 to $200 \mu \mathrm{g} \mathrm{l}^{-1}$ (Fig. 1). We used rectilinear regression (NONLIN program; Wilkinson 1988) to quantify more precisely the food density beyond which larvae were satiated (hereafter referred to as the critical food density), and to quantify the laboratory functional response at food densities below this level. This program iterates until it converges to parameter estimates that equalize the residual sum of squares for the inclining and plateau portions of the functional response relationship. Consequently, final parameter estimates are based on the entire range of food densities used in our data set.

This analysis (Model 3, Table 4 ) of residual variation from Model 2 revealed that the critical food density at which satiation occurred was $173 \mu \mathrm{g} \mathrm{l^{-1 }}$ (95\% confidence limits $=107$ to $280 \mu \mathrm{gl} \mathrm{l}^{-1}$ ). At food levels below the critical food density of $173 \mu \mathrm{g} \mathrm{l}^{-1}$, ingestion rates increased with food density in an approximately linear fashion (regression coefficient $=0.869 ; 95 \%$ confidence limits $=0.657$ to 1.080$)$. Because nonlinear parameter estimates are approximations (Wilkinson 1988), and because of the variance in our data set, we did not attempt to distinguish between the 3 types of functional response curves reported by Holling (1959).

Many functional response relationships have been effectively modelled using a negative exponential equation, $\operatorname{Res}=\operatorname{Res}_{\max }\left(1-\mathrm{e}^{-(\text {(alog Food) }}\right)$ (e.g. Ivlev 1961 , Houde \& Schekter 1980, SAS 1985b). We, therefore, fitted the negative exponential model to the data in Fig. 1 to compare its explanatory power with the recti- 
linear model. The negative exponential model $\left(\right.$ Res $\left.=0.391-3.529 e^{(-1.077 \log \text { Food) }}\right)$ explained slightly less variance $\left(\mathrm{R}^{2}=0.54\right)$ than the rectilinear model (Fig. $1 ; \mathrm{R}^{2}=0.55$ ).

Given this finding, we prefer the rectilinear regression model because it (1) explicitly identifies the food density (and its confidence limits) at which ingestion rates become satiated, (2) has fewer parameters than other models (Holling 1959, Ivlev 1961) across the range of food densities that larvae are likely to encounter in nature (Fig. 2B), (3) has power equal to more complex models in explaining the variance in ingestion rates detrended for the effects of larval size and experimental temperature; (4) easily accomodates additional significant variables if required (e.g. laboratory artifacts)

We next developed a multivariate model (Model 4, Table 4) employing larval size, temperature and food density as inputs; food density was again treated rectilinearly (Wilkinson 1988). The resulting model (Model 4) is statistically equivalent to combining Model 2 and Model 3.

Model 4 indicated that the average-sized larva (132.4 $\mu g_{i}$ Table 5) in our data set became satiated at a food density of $185 \mathrm{ug} \mathrm{l}^{-1}$ (95\% confidence limits $=158$ to $217 \mu \mathrm{g} \mathrm{I}^{-1}$; average temperature $=18.7^{\circ} \mathrm{C}$ ). This critical food density does not differ significantly from the output of Model 3. The predicted maximum ingestion rate for a $132.4 \mu \mathrm{g}$ larva at $18.7^{\circ} \mathrm{C}$ at food densities equalling or exceeding the critical food density was $75.8 \mu \mathrm{g} \mathrm{d}^{-1}\left(57.0 \%\right.$ of dry body weight $\mathrm{d}^{-1}$; Table 4 ).

\section{Laboratory induced biases in ingestion rate estimates}

The only experimental variables significantly correlated with residual variation from Model 4 were prey type and prey size (respectively, $R=-0.22 ; \mathrm{p}=0.02 ; \mathrm{R}$ $=0.22 ; \mathrm{p}=0.02 ; \mathrm{N}=109$ ). Larvae fed wild zooplankton consumed less food than those fed Artemia or Brachionus, and larvae offered larger prey ingested more food than those fed smaller prey.

Artemia nauplii were among the heaviest food organisms offered in these studies (Table 1). These nauplii are also slow, inefficient swimmers compared to copepod nauplii (Gauld 1959). Our results are therefore consistent with the hypothesis that fish larvae are most effective at capturing large, slow-swimming prey. However, prey preferences are known to vary widely among different species of larval fish and to depend on the behaviour of both larvae and prey, and on prey size and color (Checkley 1982, Peterson \& Ausubel 1984). Generalizations are therefore difficult and dangerous. The strongest result of this analysis was the fact that the effects of prey type and prey size were very small

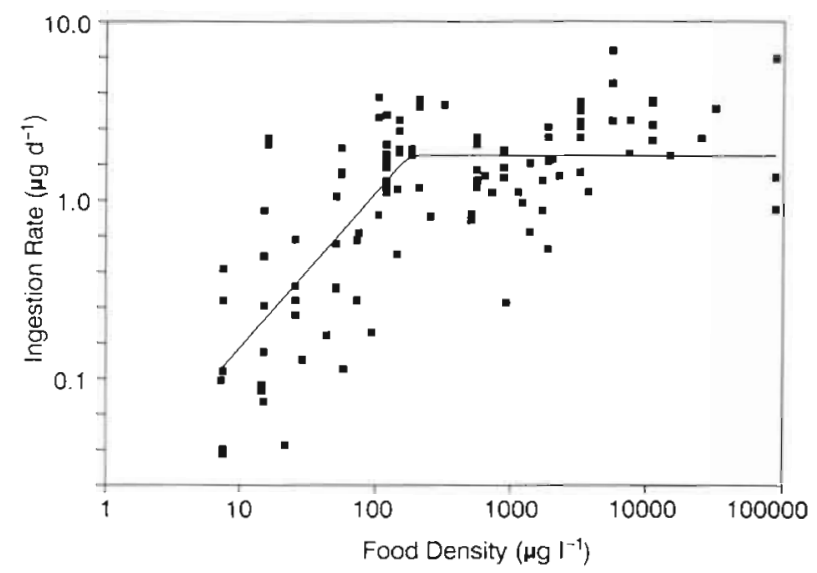

Fig. 1. Scatterplot of larval ingestion rates determined in laboratory experiments and expressed as a function of food density. The effects of larval size and experimental temperature were removed using Model 2 (Table 4) to isolate the influence of food density on ingestion rates. The fitted curve reflects a rectilinear model (Model 3, Table 4) which explicitly defines the critical food density at which satiation occurs

relative to the effects of size, temperature and food density.

Fish density and container volume did not systematically bias the estimates of ingestion rate $(p=0.86 ; N=$ 70 and $\mathrm{p}=0.23, \mathrm{~N}=88$ respectively). This observation is inconsistent with the results of enclosure and mesocosm experiments which have typically yielded growth rates that were higher than those reported from laboratory tanks (Blaxter 1988). We conclude that the modest number and range of experimental conditions (Table 5) in our data set and the potential for confounding variables precluded the identification of such artifacts. For example, the positive correlation between larval and food densities $\left(R^{2}=0.53 ; p<0.0001 ; N=70\right)$ in the experiments we surveyed may have reduced the likelihood that unnaturally high laboratory fish densities would suppress individual feeding rates.

\section{Species-specific ingestion rates}

The cumulative influence of size, temperature and food density on feeding rates in our data set is large (Table 4), and the influence of experimental factors on standardized feeding rates in our data set was relatively small. This suggests that the residual variation about Model 4 could be related to interspecific differences. This variation can be partitioned on a speciesspecific basis as follows:

$$
I_{S}=100 \operatorname{antilog}\left[\sum_{i=1}^{N}\left(\log I_{10}-\log I_{1 p}\right) / N\right]
$$

where $I_{\mathrm{s}}=$ average relative ingestion rate for species $\mathrm{s}$; $\log \mathrm{I}_{\mathrm{io}}=$ observed ingestion rate for each individual of 
species $\mathrm{s} ; \log I_{1 p}=$ predicted ingestion rate (Model 4 ) within species $s$ for each combination of larval size, water temperature and food density; $\mathrm{N}$ = number of larvae whose ingestion rates were estimated for species $s$.

This partitioning allows a relative comparison of species-specific standardized ingestion rates. The resulting ranking suggests that the average ingestion rate for each of the 11 species represented in our data set lies within a factor of ca 2 of rates predicted by Model 4 (Table 6). This comparison must be considered approximate because methodological factors may covary with the species used in our analyses.

The validity of general regression models should always be checked against independent evidence because they incorporate a number of assumptions and approximations. To achieve this independent test, we next evaluated the ingestion rates predicted by Model 4 by comparison with other fish bioenergetic models. The fraction of ingested energy used for routine metabolism can be estimated by combining Model 4 with a general model of fish respiration at $20^{\circ} \mathrm{C}$ (Winberg 1956, Peters 1983). We assumed that larvae were feeding at their maximum rates. After allowing for the influence of temperature on larval ingestion rates and converting to common units (ingestion rate: watts; larval size: $\mu \mathrm{g}$ dry weight), the proportion of ingested energy used for routine metabolism by a $132.4 \mu \mathrm{g}$ larval fish was found to be $31 \%$. This value is not significantly different from the average of those that have been experimentally determined (mean \pm standard error $=28 \pm 4.1 \%$; Table 7 )

An estimate of gross growth efficiency (G/I) can be similarly derived if one assumes that

$$
a I=R+G
$$

where $a=$ the physiologically useful fraction of ingested food ( $a=0.8$ : see Winberg 1956, Paloheimo \& Dickie 1966; $a=0.7$ : Ware 1975, Boehlert \& Yoklavich 1984); I = ingested energy; $R=$ energy respired for all metabolic demands (i.e. $\mathrm{R}=0.31 \mathrm{I}$ ); $\mathrm{G}=$ energy retained as body tissue (i.e. growth rate). Using this model, the average-sized larva in our data set was estimated to have a gross growth efficiency of 39 to $49 \%$. This estimate seems reasonable when compared with those measured experimentally among larvae which were not food-limited (mean \pm standard error $=$ $33 \pm 4.8 \%$; Table 7 ).

These comparisons lead us to conclude that Model 4 can be used to develop a priori estimates of laboratory feeding rates for larvae of fish species which cannot be (or have not been) raised in captivity. The model also facilitates post-hoc comparisons of feeding rates estimated with other methods. For example, Bailey (1982) used respirometry and growth experiments to estimate
Table 6. Relative species-specific ingestion rates after removing the effects of larval size, experimental temperature and food density using Model 4 (Table 4)

\begin{tabular}{|lcc|}
\hline Species & $\begin{array}{c}\text { Relative } \\
\text { ingestion } \\
\text { rate }\end{array}$ \\
& Reference \\
\hline Ammodytes americanus & 0.45 & 7 \\
Pagrus major & 0.70 & 6 \\
Blennius pavo & 0.72 & 5 \\
Achirus lineatus & 0.83 & 3 \\
Clupea harengus (Baltic) & 0.85 & 5 \\
Anchoa mitchilli & 0.87 & 3,10 \\
Archosargus rhomboidalis & 0.95 & 3,8 \\
Leiostomus xanthurus & 1.22 & 2 \\
Scomber japonicus & 1.27 & 4 \\
Centropristis striata striata & 1.34 & 10 \\
Engraulis mordax & 1.60 & 9 \\
Clupea harengus (Clyde) & 1.74 & 11 \\
Morone saxatilus & 2.02 & 1 \\
1. Chesney (1989); 2, Govoni et al. (1982); 3, Houde \& \\
Schekter (1981); 4, Hunter \& Kimbrell (1980); Klumpp \& \\
von Westernhagen (1986); 6, Kuronuma \& Fukusho (1984); \\
7. Monteleone \& Peterson (1984); 8, Stepien (1976); \\
9. Theilacker (1987); 10, Tucker (1989); 11, Werner \& \\
Blaxter (1981)
\end{tabular}

Table 7 Laboratory estimates of the percentages of ingested energy which are used for metabolism $R / I$ and growth $G / I$ in larval marine fish. In all cases, ingestion rates were not foodlimited

\begin{tabular}{|c|c|c|c|}
\hline Species & $\mathrm{R} / \mathrm{I}$ & $\mathrm{G} / \mathrm{I}$ & Reference \\
\hline Anchoa lineatus & 18 & 20 & 3 \\
\hline Anchoa mitchilli & 23 & 10 & 8 \\
\hline Anchoa mitchilli & 9 & 14 & 3 \\
\hline Archosargus rhomboidalis & 22 & 38 & 3 \\
\hline Archosargus rhomboidalis & - & 27 & 6 \\
\hline Blennius pavo & 38 & 60 & 5 \\
\hline Centropristus striata striata & 30 & 15 & 8 \\
\hline Clupea harengus (Baltic) & 55 & 23 & 5 \\
\hline Clupea harengus (Clyde) & - & 40 & 2 \\
\hline Clupea harengus (mixed) & - & 62 & 4 \\
\hline Engraulis mordax & 17 & 30 & 7 \\
\hline Merluccius productus & 28 & 42 & 1 \\
\hline Pleuronectes platessa & 37 & 54 & 5 \\
\hline Mean & 28 & 33 & \\
\hline Standard error & 4.1 & 4.8 & \\
\hline \multicolumn{4}{|c|}{$\begin{array}{l}\text { 1, Bailey (1982); 2, Checkley (1984); 3, Houde \& Schekter } \\
\text { (1981, 1983); 4, Kiørboe et al. (1987); 5, Klumpp \& von } \\
\text { Westernhagen (1986); 6, Stepien (1976); 7, Theilacker } \\
(1987) ; 8 \text {, Tucker (1989) }\end{array}$} \\
\hline
\end{tabular}

that first-feeding Pacific hake Merluccius productus larvae require $26 \mu \mathrm{g}$ of prey per day to meet metabolic and growth demands $\left(\mathrm{T}=12{ }^{\circ} \mathrm{C}\right.$; mean size of firstfeeding larvae $=75.1 \mu \mathrm{g}$; Table 5; Bailey 1982). This estimate is identical to that predicted by Model 4 for 
larvae whose feeding rates are not food-limited. Ingestion rates by other species, however, could deviate by ca 2 -fold from predictions made by Model 4 (Table 6).

\section{Comparison of laboratory derived functional response with natural microzooplankton densities}

The frequency distribution of natural zooplankton densities (Fig. 2B) suggests that larvae equivalent in size to the average in our data set $(132.4 \mu \mathrm{g})$ will be unable to feed at maximal rates in nature (Fig. 2). This assumes, of course, that our derived ingestion rates can be extrapolated to the wild. This comparison also suggests that larval ingestion rates are most sensitive to changes in food abundance across the range of food densities that are most likely to occur in nature (Fig. 2A, B). Consequently physical processes (e.g. Lasker 1975) and/or behaviours (Hunter \& Thomas 1974, Fortier \& Leggett 1982, Munk \& Kiørboe 1985) which affect local distributions of larvae and their prey can be expected to have a dramatic effect on larval feeding rates in nature.

\section{Natural ingestion rate model}

The data set representing estimates of ingestion rates for wild larvae contained estimates for 8 species. The ranges of temperature and food density reported in these studies were 4.5 to $30.7^{\circ} \mathrm{C}$ and 3.9 to $210 \mu \mathrm{g} \mathrm{l^{-1 }}$ respectively. An empirical model of food ingestion rate based on larval size, in situ temperature and in situ food densities revealed that only size and temperature were significant predictors (Model 5). Natural rates were independent of food density ( $p=0.22$ ).

To facilitate direct comparison between wild and laboratory ingestion rates, we standardized ingestion rates of wild larvae for different larval sizes and water temperatures using Model 2 which we derived from laboratory data (Table 4). Thus standardized, feeding rates estimated for wild larvae typically exceeded those estimated from laboratory data at equivalent food densities (Fig. 2A).

\section{Synthesis}

As anticipated, larval size, temperature and food density were the dominant sources of variance in laboratory based estimates of ingestion rate. In the data set we developed, ingestion rates detrended for the effects of larval size and experimental temperature reached a maximum at food densities exceeding 185 uq $\mathrm{l}^{-1}\left(95 \%\right.$ confidence limits $=158$ to $\left.217 \mathrm{~kg} \mathrm{l}^{-1}\right)$.
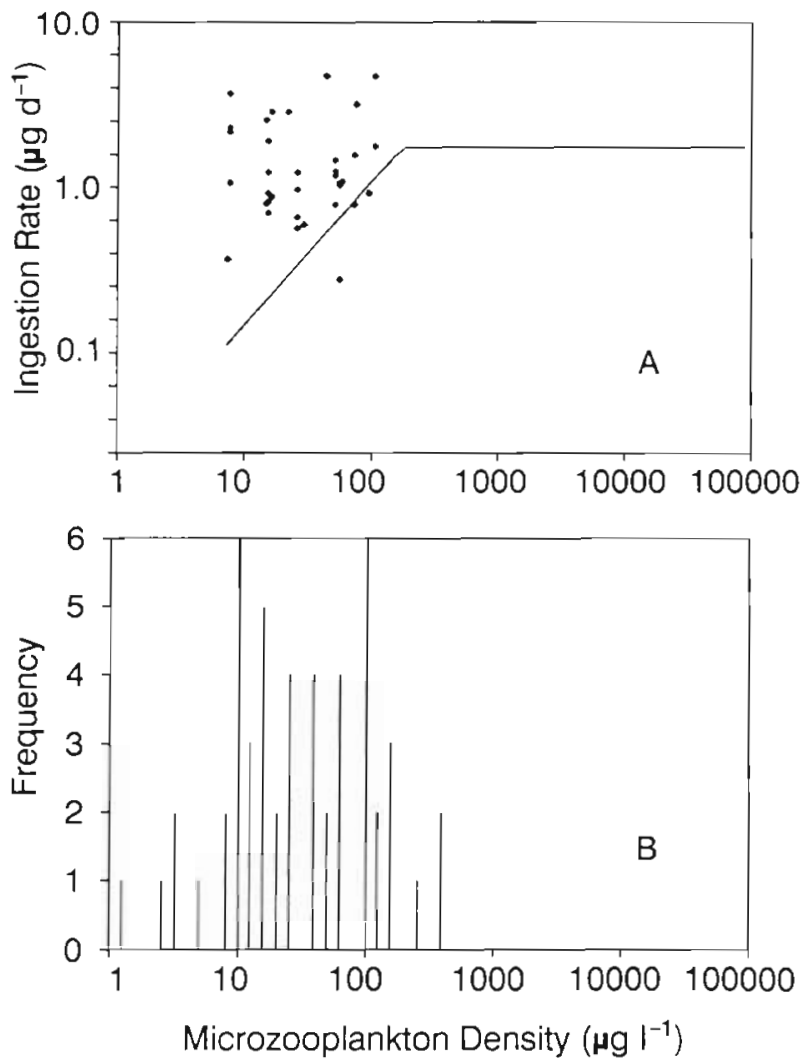

Fig. 2. (A) Scatterplot of ingestion rate estimates for wild larvae, and for larvae reared in mesocosms after the effects of larval size and experimental temperature have been removed using Model 2. The fitted line is that described by Model 3. (B) Frequency distribution of average microzooplankton densities sampled at 46 marine sites around the world. The median and 90 th percentile of these data occur at 31 and $148 \mu \mathrm{g} \mathrm{l}^{-1}$. respectively. All samplers used in these studies were capable of retaining particles $<200 \mu \mathrm{m}$. The geographical locations, their corresponding food densities and data sources are listed in Table 2

Although methodological effects were relatively small for this data set, 2 caveats are necessary. First, container size effects are known to occur if the range of container size is expanded. For example, mesocosm studies, while few in number to date, typically yield higher growth rates than those found using container sizes commonly used in laboratory studies (Diestad 1985, Blaxter 1988). Second, in the experimental studies we evaluated, investigators exhibited a tendency to compensate for higher larval densities by providing higher prey densities. This may have otherwise obscured an obvious effect of methodology. These potential biases require further study.

The laboratory-based ingestion rate estimates we evaluated showed a sharp functional response in which satiation occurred only at prey densities near or above the maximum densities typically found at sea. If these results are realistic representations of feeding rates in the sea, larval ingestion rates in the wild are likely to be 
significantly below the maximum levels possible in most areas where larvae are found in nature.

However the independence of ingestion rates estimated for wild larvae and estimates of food density in the sea, coupled with the fact that these rates are uniformly near the maximum levels observed in laboratory studies, strongly suggests that laboratory functional response models seriously misrepresent natural feeding rates. However, before accepting this conclusion several alternative explanations should be explored.

The low correspondence between ingestion rate estimates for wild larvae and local food densities could result either from overestimation of ingestion rates for wild larvae, or, alternatively, from underestimating the larval food resource. The impact of these separate biases on the relationship between laboratory and field based estimates of ingestion rates is illustrated schematically in Fig. 3.

It is important to recognize that the estimates of wild ingestion rate in Fig. $2 \mathrm{~A}$ represent rates for larvae that have been captured by plankton samplers, and that these rates could misrepresent the average ingestion rate for a given cohort. For example, if the larvae captured are the most effective individual foragers within a cohort, their ingestion rates, and levels of activity (Laurence 1972, Frank \& Leggett 1982b, Yin \& Blaxter 1987), would probably be higher than the average rate for the entire cohort. Average ingestion rates could be considerably lower than the maximum individual rate because of differences in capture success, attack success and swimming ability between individuals of equal size (Vladimirov 1975, Houde \& Schekter 1980 , p. 331). It is possible, therefore, that if the least active larvae had been removed from the water column by predators (Bailey \& Batty 1984) prior to sampling, the resulting estimates of field ingestion rates could overestimate the population average.

Secondly, in our analyses we estimated 31 of 36 wild ingestion rates from reported in situ larval growth rates using a previously published growth model derived entirely from laboratory populations of larval fish (Checkley 1984). The extrapolation of this model to wild larvae by ourselves and others (e.g. Walline 1987) explicitly assumes that gross growth efficiencies of wild larvae are equivalent to those of laboratory populations. If gross growth efficiencies are higher in wild larvae, the ingestion rates we estimated from field growth rates using the Checkley model (1984) would be overestimated

However, these 2 potential sources of positive bias could be partially offset by others which could lead to underestimates of wild ingestion rates. For example, prey activity stimulates feeding responses in many predators of larval fish (e.g. chaetognaths and some

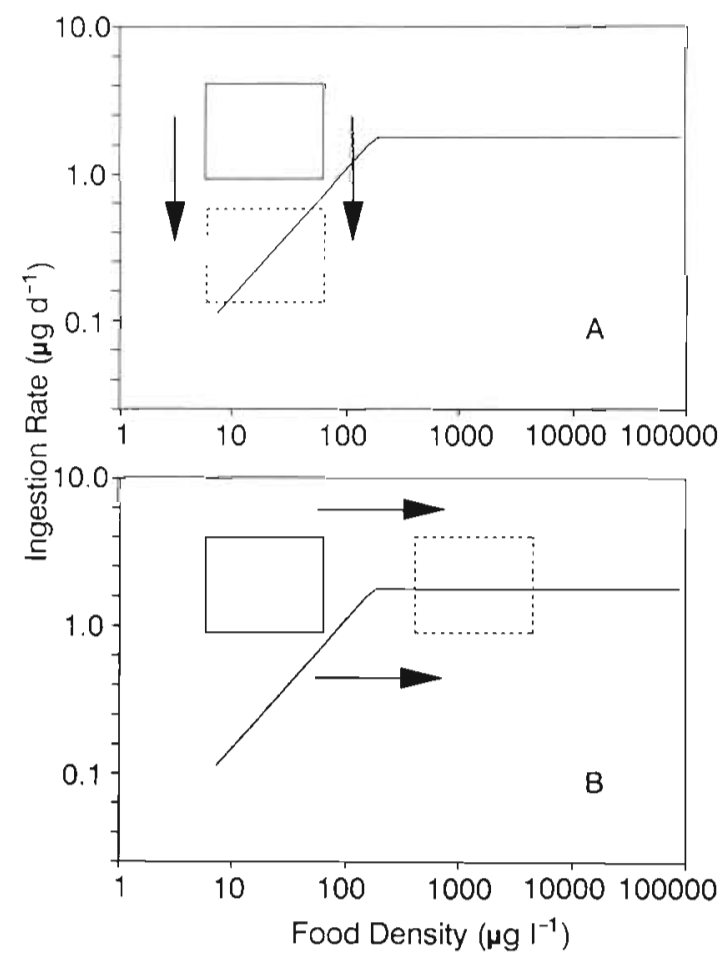

Fig. 3. Schematic diagram offering 2 possible explanations for the observed high ingestion rates (larval size and temperature effects removed using Model 2) reported for wild larvae, relative to those determined from laboratory studies at equivalent prey densities. (A) Feeding rates overestimated for a given food density. (B) Larvae encounter prey at higher rates than census measures of food density would indicate. In the latter case, observed ingestion rates would reflect the frequency of encounters between larvae and prey, but not the numerical densities of prey

species of copepods, amphipods and euphausiids; Bailey \& Houde 1989). Because poorly-fed larvae are less active than well-fed larvae (Laurence 1972, Blaxter \& Ehrlich 1974, Frank \& Leggett 1982b), poorly-fed larvae will stimulate relatively fewer of those predators who rely on prey movement to elicit feeding stimuli. Lower activity levels in poorly nourished larvae could also reduce their encounter rate with slow-moving and ambush predators (p. 12 in Bailey \& Houde 1989). Consequently, under some circumstances, these interactions could allow weakened larvae to remain in the water column longer than more active larvae. If this bias was common in the studies we surveyed, it could result in an underestimation of field ingestion and/or growth rates.

Moreover, daytime plankton collections could overestimate the relative abundance of poorly-fed larvae because such larvae are probably less able to detect and avoid capture by plankton samplers (see Blaxter \& Ehrlich 1974).

We also acknowledge that capture by plankton gear causes some species of larvae to regurgitate or defecate the contents of their guts (e.g. Hay 1981). However this 
effect, and other potential sources of bias in determining ingestion rates from gut contents and clearance data (e.g. different digestibilities of various prey types; Rosenthal \& Hempel 1970), is likely to be small in our case because only 5 of the 36 field ingestion rates we report and used were based on the analysis of gut contents.

The cumulative magnitude and direction of these potential sources of bias is difficult to assess without a better knowledge of how different predators encounter and capture larvae that are feeding and growing at different rates in situ. Until such information becomes available we cannot exclude the possibility that the wild ingestion rates in our data set are biased by these and possibly other considerations.

However, we do believe that there is sufficient information available regarding in situ zooplankton abundance estimates to question whether these estimates adequately reflect larval prey availability. For example, estimates of prey standing stock are known to neglect zooplankton production rates which typically range from 0.5 to $2.0 \mu \mathrm{g} \mathrm{l}^{-1} \mathrm{~d}^{-1}$ in continental shelf ecosystems (Middlebrook \& Roff 1986, McLaren et al. 1989). Moreover, episodic production events can greatly increase rates of plankton production. These phenomena are common both in nearshore regions (Tont 1981, Arcos \& Wilson 1984, Atkinson et al. 1984. Takahashi et al. 1986, Lohrenz et al. 1988, Thresher et al. 1989) and in offshore areas of continental shelves (Checkley et al. 1988, Frank \& Carscadden 1989). In addition, this new production is typically in the size range (e.g. Mullin et al. 1985, Checkley et al. 1988) required by early stages of larvae (Hunter 1981, Frank \& Leggett 1986). Despite the probable importance of transient production events to larval feeding success, their influence is difficult to quantify and forecast with conventional methods (Coté \& Platt 1983, Thresher et al. 1989).

Zooplankton is also known to be patchily distributed in the sea on the spatial scale of larval feeding activity (metres to 100's of metres; see Jenkins 1988, Owen 1989). For example, the median prey density within a patch has been reported to be twice the density that would be obtained with integrative sampling gear (Owen 1989). However, patch intensity number of prey per patch) can range up to 10 -fold higher than an integrated density estimate, particularly if wind speeds are favorable (Owen 1989). As a consequence, estimates of prey density based on integrative sampling techniques are likely to be much lower than those actually experienced by fish larvae (review by Leggett 1986, Jenkins 1988, Owen 1989).

Census estimates of prey density also fail to incorporate the positive effects of small-scale turbulence on plankton contact rates (Rothschild \& Osborn 1988).
Larvae of other aquatic taxa are known to exploit micro-scale differences in the physical environment to improve feeding success (e.g. black flies Simulium vittatum; Morin \& Peters 1988, Ciborowski \& Craig 1989). It seems plausible, therefore, that larval fish may also be capable of exploiting physical variability in their habitat for similar purposes.

Finally, larval fish are known to swim faster in nature than when confined in laboratory tanks (von Westernhagen \& Rosenthal 1979). Greater routine swimming speeds by wild larvae relative to those reared in the laboratory would cause wild larvae to search larger volumes, thereby increasing the potential for contacts between larvae and prey

For all of these reasons, we believe that underestimation of the frequency of contacts between larvae and prey in nature is a major factor influencing the discrepancy between laboratory and in situ ingestion rates (Fig. 2). Similarly our comparisons suggest that failure to design laboratory experiments that account for processes that benefit high rates of contact between larvae and their prey (e.g. larval behaviours, patchiness, turbulence) are certain to result in low feeding rates, unless researchers provide unnaturally high prey densities in an attempt to compensate for artificial rearing conditions. Consequently those studies which are most effective at replicating the natural environment can be expected to produce growth rates approdching those observed in nature (e.g. Kiørboe \& Munk 1986).

Our observation that fish larvae in the sea can feed at rates near satiation, and that these rates appear to be largely independent of food density, is consistent with the results of several recent studies. High resolution sampling has shown that mortality rates can be independent of the food resource, in spite of large-scale variations in food abundance (Taggart \& Leggett 1987), and confirms that prey densities in some nursery areas, where such sampling techniques have been employed, are unlikely to limit feeding rates (Jenkins 1987, 1988, Fortier \& Harris 1989).

It must be acknowledged, however, that the absence of a relationship between natural ingestion or growth rates and food density is not universal (e.g. Frank \& Leggett 1982a, 1986, Buckley \& Lough 1987, Kiørboe et al. 1988) However typical in situ prey densities, when coupled with appropriate interactions between prey distributions, the physical environment (e.g smallscale turbulence; Rothschild \& Osborn 1988), and larval feeding and diel migratory behaviours (Hunter \& Thomas 1974, Heath et al. 1988, Munk et al. 1989) appear to be sufficient to allow many larval populations to feed at near-maximal rates in nature. In the absence of these (and possibly other) interactions, feeding rates at food densities < ca $185 \mathrm{\mu g}^{-3}$ will probably be sub- 
maximal and could approach those predicted by our laboratory based functional response model (Model 4).

In particular, much of the potential variability in larval feeding rates that might be expected to occur in the sea because of natural variation in food densities has probably already been dampened by spawning behaviour: the spawning activity of temperate and boreal species of fish is known to be highly restricted in time and space (Sinclair 1988). We suspect that the historical average for the larval food resource at these times/places may be more suitable for larval feeding than at other times or places (see also Kiørboe \& Johansen 1986). Interannual variations in hydrodynamic regimes, which are largely beyond the control of larvae and which influence recruitment (Cury \& Roy 1989) and larval survival (Peterman \& Bradford 1987) may, therefore, exert their influence through their effects on feeding success. These effects could simultaneously increase (or decrease) both the density of prey and the frequency of contacts between larval fish and their prey.

We conclude that increased attention to factors that influence the small-scale temporal and spatial dynamics of interactions between larval fish and their prey would contribute meaningfully to the resolution of the oldest question in recruitment dynamics 'Does food abundance and its availability to larvae regulate yearclass strength in fishes?"

Acknowledgements. Earlier versions of this work were presented at the 13th Annual Larval Fish Conference of the American Fisheries Society, Mérida, Mexico, May 21-27. 1989, and at the Canadian Conterence for Fisheries Research. Ottawa, Ontario, Canada Jan 3-4, 1990; we thank those colleagues who provided us with useful comments and criticisms. We also thank John Anderson, Chris Chambers and Ken Frank for their constructive reviews of the manuscript. B.R.M. was supported by a Natural Sciences and Engineering Research Council post-graduate scholarship.

\section{LITERATURE CITED}

Äksnes, D. L., Magnesen, T. (1988). A population dynamics approach to the estimation of production of four calanoid copepods in Lindåspollene, western Norway. Mar. Ecol. Prog. Ser. 45: 57-68

Äksnes, D. L., Aure, J. Kaartvedt, S., Magnesen, T., Richard, J. (1989). Significance of advection for the carrying capacities of fjord populations. Mar. Ecol. Prog. Ser 50: 263-274

Anderson. J. T. (1988). A review of size dependent survival during pre-recruit stages of fishes in relation to recruitment. J. Northw. Atl. Fish. Sci. 8: 55-66

Arcos, D. F., Wilson, R. E. (1984). Upwelling and the distribution of chlorophyll a within the Bay of Concepción, Chile. Estuar. coast. Shelf Sci. 18: 25-35

Atkinson, L. P., O'Malley, P. G., Yoder, J. A., Paffenhöfer, G.
A. (1984). The effect of summertime shelf break upwelling on nutrient flux in southeastern United States continental shelf waters. J. mar Res. 42: 969-993

Bailey, K. M. (1982). The early life history of the Pacific hake Merluccius productus. Fish. Bull. U.S. 80: 589-598

Bailey, K. M., Batty, R. S. (1984). Laboratory study of predation by Aurelia aurita on larvae of cod, flounder, plaice and herring: development and vulnerability to capture. Mar Biol. 83: 287-291

Bailey, K. M., Stehr, C. L. (1986). Laboratory studies on the early life history of the walleye pollock. Theragra chalcogramma (Pallas). J. exp. mar Biol. Ecol. 99: 233-246

Bailey, K. M., Houde, E. D. (1989). Predation on eggs and larvae of marine fishes and the recruitment problem. Adv. mar Biol. 25: 1-83

Bämstedt, U. (1986). Chemical composition and energy content. In: Corner, E. D. S., O'Hara, S. C. M. (eds.) The biological chemistry of marine copepods. Oxford University Press, Oxford, p. 1-58

Barahona-Fernandes, M. H., Conan, G. (1981). Daily food intake of reared larvae of the European seabass (Dicentrarchus labrax L.). Statistical analysis and modelling. Rapp. P-v. Réun. Cons. int. Explor Mer 178: 41-44

Beers, J. R., Stewart, G. L. (1967). Micro-zooplankton in the euphotic zone at five locations across the California Current. J. Fish. Res. Bd Can. 24: 2053-2068

Beers, J. R., Stewart, G. L. (1969). Microzooplankton and its abundance relative to the larger zooplankton and other seston components. Mar. Biol. 4: 182-189

Benijts, F., van Voorden, E., Sorgeloos, P. (1975). Changes in the biochemical composition of the early larval stages of the brine shrimp, Artemia salina L. In: Persoone, G., Jaspers, E. (eds.) Proc. 10th European Mar. Biol. Symp., Vol. 1 Mariculture. Universa Press, Wetteren, Belgium, p. 1-9

Blackburn, M., Nellen, W (1976). Distribution and ecology of pelagic fishes studied from eggs and larvae in an upwelling area off Spanish Sahara. Fish. Bull. U.S. 74: 885-896

Blaxter, J. H. S. (1988). Pattern and variety in development. In: Hoar, W. S., Randall, D. J. (eds.) Fish physiology, Vol. XI. The physiology of developing fish, Part A: Eggs and larvae. Academic Press, New York, p. 1-58

Blaxter, J. H. S., Ehrlich, K. F. (1974) Changes in behaviour during starvation of herring and plaice larvae. In: Blaxter, J. H. S. (ed.) The early life history of fish. Springer-Verlag, Berlin, p. $575-588$

Boehlert, G. W., Yoklavich, M. M. (1984). Carbon assimilation as a function of ingestion rate in Pacific herring. Clupea harengus pallasi Valenciennes. J. exp. mar. Biol. Ecol. 79 : 251-262

Buckley, L. J., Lough, R. G. (1987). Recent growth, biochemical composition, and prey field of larval haddock (Melanogrammus aeglefinus) and Atlantic cod (Gadus morhua) on Georges Bank. Can. J. Fish. Aquat. Sci. 44: $14-25$

Burkhill, P. H., Kendall, T. F. (1982). Production of the copepod Eurytemora affinis in the Bristol Channel. Mar. Ecol. Prog. Ser. 7: 21-31

Checkley, D. M. Jr (1982). Selective feeding by Atlantic herring (Clupea harengus) by larvae on zooplankton in natural assemblages. Mar Ecol. Prog. Ser. 9: 245-253

Checkley, D. M. Jr (1984). Relation of growth to ingestion for larvae of Atlantic herring Clupea harengus and other fish. Mar. Ecol. Prog. Ser. 18: 215-224

Checkley, D. M. Jr, Raman, S., Maillet, G. L., Mason, K. M. (1988). Winter storm effects on the spawning and larval drift of a pelagic fish. Nature, Lond. 335: 346-348

Chesney, E. J. Jr (1989). Estimating the food requirements of 
striped bass larvae Morone saxatilus: effects of light, turbidity, and turbulence. Mar Ecol. Prog. Ser. 53: 191-200

Cirobowski, J. J. H., Craig, D. A. (1989). Factors influencing dispersion of larval black flies (Diptera:Simuliidae): effects of current velocity and food concentration. Can. J. Fish. Aquat. Sci. 46: 1329-1341

Coté, B., Platt, T (1983). Day-to-day variations in the springsummer photosynthetic parameters of coastal marine phytoplankton. Limnol. Oceanogr. 28: 320-344

Cury, P., Roy, C. (1989). Optimal environmental window and pelagic fish recruitment success in upwelling areas. Can. J Fish. Aquat. Sci. 46: 670-680

Dagg, M. J., Clarke, M. E., Nishiyama, T., Smith, S. L. (1984) Production and standing stock of copepod nauplii, food items for larvae of the walleye pollock Theragra chalcogramma in the southeastern Bering Sea. Mar. Ecol. Prog Ser. 19: 7-16

Davis, C. S. (1984). Food concentrations on Georges Bank: nonlimiting effect on development and survival of laboratory reared Pseudocalanus sp. and Paracalanus parvus (Copepoda, Calanoida). Mar. Biol. 82: 41-46

Deevey, C. B. (1952). Quantity and composition of the zooplankton of Block Island Sound, 1949. Bull. Bingham Oceanogr. Coll. 13: 120-164

DeLafontaine, Y., Leggett, W C. (1987). Effect of container size on estimates of mortality and predation rates in experiments with macrozooplankton and larval fish. Can. J. Fish. Aquat. Sci. 44: 1534-1543

DeLafontaine, Y., Leggett, W. C. (1989). Changes in size and weight of hydromedusae during formalin preservation. Bull. mar Sci. 44: 1129-1137

Durbin, A. G., Durbin, E. G. (1981). Standing stock and estimated production rates of phytoplankton and zooplankton in Narragansett Bay, Rhode Island. Estuaries 4: 24-41

Ellertsen, B., Fossum, P., Solemdal, P., Sundby, S., Tilseth, S (1984). A case study on the distribution of cod larvae and availability of prey organisms in relation to physical processes in Lofoten. In: Dahl, E., Danielssen, D. S., Møksness, E., Solemdal, P. (eds.) The propagation of cod Gadus morhua L. Arendal, Norway. Flodevigen rapportser. 1: $453-477$

Evans, F. (1977). Seasonal density and production estimates of the commoner planktonic copepods of Northumberland coastal waters. Estuar. coast. mar. Sci. 5: 223-241

Fortier, L., Leggett, W. C. (1982). Fickian transport and the dispersal of fish larvae in estuaries. Can. J. Fish. Aquat. Sci. 39: 1150-1163

Fortier, L., Harris, R. P. (1989). Optimal foraging and densitydependent competition in marine fish larvae. Mar. Ecol. Prog. Ser 51: 19-33

Foster, B. A., Battaerd, W. R. (1985). Distribution of zooplankton in a coastal upwelling in New Zealand. N.Z.Jl mar. Freshwat. Res. 19: 213-226

Frank, K. T (1988). Independent distributions of fish larvae and their prey: natural paradox or sampling artifact. Can. J. Fish. Aquat. Sci. 45: 48-59

Frank, K. T., Leggett, W. C. (1982a). Coastal water mass replacement: its effect on zooplankton dynamics and the predatorprey complex associated with larval capelin $(\mathrm{Mal}$ lotus villosus). Can. J. Fish. Aquat. Sci. 39: 991-1003

Frank, K. T., Leggett, W. C. (1982b). Environmental regulation of growth rate, efficiency, and swimming performance in larval capelin (Mallotus capelin), and its application to the match/mismatch hypothesis. Can. J. Fish. Aquat. Sci. 39: $691-699$

Frank, K. T., Leggett, W C. (1986). Effect of prey abundance and size on the growth and survival of larval fish: an experimental study employing large volume enclosures Mar. Ecol. Prog. Ser. 34: 11--22

Frank, K. T., Carscadden, J. E. (1989). Factors affecting recruitment variability of capelin (Mallotus villosus) in the Northwest Atlantic. J. Cons. 45: 146-164

Fransz, H. G., Miguel, J. C., Gonzalez, S. R. (1984). Mesozooplankton composition, biomass and vertical distribution, and copepod production in the stratified central North Sea. Neth. J. Sea Res. 18: 82-96

Gamble, J. C., Houde, E. D. (1984), Growth, mortality, and feeding of cod (Gadus morhua L.) larvae in enclosed water columns and in laboratory tanks. In: Dahl, E., Danielssen, D. S., E. Moksness, E., Solemdal, P. (eds.) The propagation of cod Gadus morhua L. Arendal, Norway. Flodevigen Rapportser. 1: 123-143

Gamble, J. C. MacLachlan, P., Seaton, D. D. (1985). Comparative growth and development of autumn and spring spawned Atlantic herring larvae in large enclosed ecosystems. Mar. Ecol. Prog. Ser. 26: 19-33

Garrett, C. J. R., Loucks, R. H. (1976). Upwelling along the Yarmouth shore of Nova Scotia. J. Fish. Res. Bd Can. 33: 116-117

Gauld, D. T. (1959). Swimming and feeding in crustacean larvae: the nauplius larva. Proc. Zool. Soc. Lond. 132: $31-50$

Giguère, L. A., Coté, B., St-Pierre, J.-F. (1988). Metabolic rates scale isometrically in larval fishes. Mar. Ecol. Prog. Ser. 50: $13-19$

Giguère, L. A., St. Pierre, J.-F., Bernier, B., Vézina, A., Rondeau, J.-G. (1989). Can we estimate the true weight of zooplankton samples after chemical preservation? Can. J. Fish. Aquat. Sci. 46: 522-527

Govoni, J. J., Peters, D. S., Merriner, J. V. (1982). Carbon assimilation during larval development of the marine teleost Leiostomus xanthurus Lacepede. J. exp. mar. Biol. Ecol. 64: $287-299$

Hargrave, B. T., Harding, G. C., Drinkwater, K. F., Lambert, T C., Harrison, W. G. (1985). Dynamics of the pelagic food web in St. Georges Bay, southern Gulf of St. Lawrence. Mar. Ecol. Prog. Ser. 20: 221-240

Hay, D. E. (1981). Effects of capture and fixation on gut contents and body size of Pacific herring larvae. Rapp. P.v. Rèun. Cons. Int. Explor. Mer 178: 395-400

Hay, D. E. (1984). Weight loss and change of condition factor during fixation of Pacific herring, Clupea harengus pallasi, eggs and larvae. J. Fish. Biol. 25: 421-433

Heath, M. R., Henderson, E. W., Baird, D. L. (1988). Vertical distribution of herring larvae in relation to physical mixing and illumination. Mar. Ecol. Prog. Ser. 47: 211-228

Heinle, D. R. (1966). Production of a calanoid copepod, Acartia tonsa in the Patuxent River estuary. Chesapeake Sci. 7 : $59-74$

Heinle, D. R., Flemer, D. A. (1975). Carbon requirements of a population of the estuarine copepod Eurytemora affinis. Mar Biol. 31: 235-247

Holligan, P. M., Harris, R. P. Newell, R. C., Harbour, D. S., Head, R. N., Linley, E. A. S., Lucas, M. I. Tranter, P. R. G., Weekley, C. M. (1984). Vertical distribution and partitioning of organic carbon in mixed, frontal and stratified waters of the English Channel. Mar. Ecol. Prog. Ser. 14: $111-127$

Holling, C. S. (1959). The components of predation as revealed by a study of small mammal predation of the European Pine Sawfly. Can. Entom. 91: 293-320

Hopkins. T L. (1977). Zooplankton distribution in surface waters of Tampa Bay, Florida. Bull. mar. Sci. 27: 467-478

Houde, E. D. (1977). Effects of stocking density and food 
density on survival, growth, and yield of laboratory-reared larvae of red sea bream, Archosargus rhomboidalis (L.) (Sparidae). J. Fish Biol. 7: 115-127

Houde, E. D. (1978). Critical food concentrations for larvae of three species of subtropical marine fishes. Bull. mar. Sci. 28: 395-411

Houde, E. D. (1989). Comparative growth, mortality and energetics of marine fish larvae: temperature and implied latitudinal effects. Fish. Bull. U.S. 87: 471-496

Houde, E. D., Schekter, R. C. (1980). Feeding by marine fish larvae: developmental and functional responses. Environ. Biol. fish. 5: 315-334

Houde, E. D., Schekter, R. C. (1981). Growth rates, rations, and cohort consumption of marine fish larvae in relation to prey concentrations. Rapp. P-v. Réun. Cons. int. Explor. Mer 178: 441-453

Houde, E. D., Schekter, R. C. (1983). Oxygen uptake and comparative energetics among eggs and larvae of three subtropical marine fishes. Mar. Biol. 72: 283-293

Hunter, J. R. (1981). Feeding ecology and predation of marine larvae. In: Lasker, R. (ed.) Marine fish larvae: morphology, ecology and relation to fisheries. Univ. of Washington Press, Seattle, p. 34-77

Hunter, J. R., Thomas, G. L. (1974). Effect of prey distribution and density on the searchin and feeding behaviour of larval anchovy Engraulis mordax. In: Blaxter, J. H. S. (ed.) The early life history of fish. Springer-Verlag Berlin, p. 559-574

Hunter, J. R., Kimbrell, C. A. (1980). Early life history of Pacific mackerel, Scomber japonicus. Fish. Bull. U.S. 78: 89-101

Ivlev, V. S. (1961). Experimental ecology of the feeding of fishes. Yale University Press, New Haven

James, M. R., Wilkinson, V. H. (1988). Biomass, carbon ingestion, and ammonia excretion by zooplankton associated with an upwelling plume in western Cook Strait, New Zealand. N. Z. J. mar. Freshwat. Res. 22: 249-257

James, A. G., Findlay, K. P. (1989). Effect of particle size and concentrations on feeding behaviour, selectivity and rates of food ingestion by the Cape anchovy Engraulis capensis. Mar. Ecol. Prog. Ser. 30: 275-294

Jenkins, G. P. (1987). Comparative diets, prey selection, and predatory impact of co-occurring larvae of two flounder species. J. exp. mar. Biol. Ecol. 110: 147-170

Jenkins, G. P. (1988). Micro- and fine-scale distribution of microplankton in the feeding environment of larval flounder. Mar. Ecol. Prog. Ser. 43: 233-244

Kahru, M., Elken, J., Kotta, I., Simm, M., Vilbaste, K. (1984). Plankton distributions and processes across a front in the open Baltic Sea. Mar. Ecol. Prog. Ser. 20: 101-111

Kiørboe, T., Johansen, K. (1986). Studies of a larval herring (Clupea harengus L.) patch in the Buchan area. IV. Zooplankton distribution and productivity in relation to hydrographic features. Dana 6: 37-51

Kiørboe, T., Munk, P. (1986). Feeding and growth of larval herring, Clupea harengus, in relation to density of copepod nauplii. Environ. Biol. Fish. 17: 133-139

Kiørboe, T., Munk, P., Richardson, K. (1987). Respiration and growth of larval herring Clupea harengus: relation between specific dynamic action and growth efficiency. Mar. Ecol. Prog. Ser. 40: 1-10

Kiørboe, T., Munk, P., Richardson, K., Christensen, V., Paulsen, H. (1988). Plankton dynamics and larval herring growth, drift and survival in a frontal area. Mar. Ecol. Prog. Ser. 44 : 205-219

Klumpp, D. W., von Westemhagen, H. (1986). Nitrogen balance in marine fish larvae: influence of developmental stage and prey density. Mar. Biol. 93: 189-199
Kuronuma, K., Fukusho, K. (1984). Rearing of marine fish larvae in Japan. International Development Research Centre, Ottawa, Ontario, Canada. IDRC-TS47e p. 1-109

Lasker, R. (1975). Field criteria for the survival of anchovy larvae: the relation between inshore chlorophyll maximum layers and successful first feeding. Fish. Bull. U.S. 73: $453-462$

Laurence, G. C. (1972). Comparative swimming abilities of fed and starved larval largemouth bass (Micropterus salmoides). J. Fish. Biol. 4: 73-78

Leak, J. C., Houde, E. D. (1987). Cohort growth and survival of bay anchovy Anchoa mitchilli in Biscayne Bay, Florida. Mar. Ecol. Prog. Ser. 37: 109-122

LeBorgne, R., Blanchot, J., Charpy, L. (1989). Zooplankton of Tikehau atoll (Tuamotu archipelago) and its relationship to particulate matter. Mar. Biol. 102: 341-353

Leggett, W. C. (1986). The dependence of fish larval survival on food and predator densities. In: Skreslet, S. (ed.) NATO ASI Series Vol. G7: The role of freshwater outflow in coastal marine ecosystems. Springer-Verlag, Berlin, p. $117-137$

Lohrenz, S. E., Arnone, R. A., Wiesenburg, D. A., DePalma, I. P. (1988). Satellite detection of transient enhanced primary production in the western Mediterranean Sea. Nature, Lond. 335: 245-247

Lonsdale, D. J., Coull, B. C. (1977). Composition and seasonality of zooplankton of North Inlet, South Carolina Chesapeake Sci. 18: 272-283

MacCauley, E. (1984). The estimation of the abundance and biomass of zooplankton in samples. In: Downing. J. A. Rigler, F. H. (eds.) A manual on methods for the assessment of secondary productivity in fresh waters, 2nd edn. Blackwell Scientific Publications, Oxford, p. 228-265

MacKenzie, A. L., Gillespie, P. A. (1986). Plankton ecology and productivity, nutrient chemistry, and hydrography of Tasman Bay, New Zealand, 1982-1984. N. Z. Jl mar. Freshwat. Res. 20: 365-395

Martens, P. (1980). Contributions to the mesozooplankton of the northern Wadden Sea of Sylt. Helgoländer wiss. Meeres. 34: 41-53

McGurk, M. D. (1986). Natural mortality of marine pelagic fish eggs and larvae: role of spatial patchiness. Mar. Ecol. Prog. Ser 34: 227-242

McLaren, I. A. (1963). Effects of temperature on growth of zooplankton and the adaptive value of vertical migration. J. Fish. Res. Bd Can. 20: 685-727

McLaren, I. A., Tremblay, M. J., Corkett, C. J., Roff, J. C. (1989). Copepod production on the Scotian Shelf based on lifehistory analyses and laboratory rearings. Can. J. Fish. Aquat. Sci. 46: 560-583

Middlebrook, K., Roff, J. C. (1986). Comparison of methods for estimating annual productivity of the copepods Acartia hudsonica and Eurytemora herdmani in Passamaquoddy Bay, New Brunswick. Can. J. Fish. Aquat. Sci. 43: 656-664

Miller, T. J., Crowder, L. B., Rice, J. A., Marschall, E. A. (1988). Larval size and recruitment mechanisms in fishes: toward a conceptual framework. Can. J. Fish. Aquat. Sci. 45: $1657-1670$

Moksness, E. (1982). Food uptake, growth and survival of capelin larvae (Mallotus villosus Muller) in an outdoor constructed basin. Fisk. Dir. Skr HavUnders. 17: 267-285

Monteleone, D. M., Peterson, W. T. (1986). Feeding ecology of American sand lance Ammodytes americanus larvae from Long Island Sound. Mar. Ecol. Prog. Ser. 30: 133-143

Morin, A., Peters, R. H. (1988). Effect of microhabitat features, seston quality, and periphyton on abundance of overwin- 
tering black fly larvae in southern Québec. Limnol. Oceanogr. 33: 431-446

Mullin, M. M., Brooks, E. R., Reid, F. M. H., Napp, J. \& Stewart, E. F. (1985). Vertical structure of nearshore plankton off southern California: a storm and a larval fish food web. Fish. Bull. U.S. 83: 151-170

Munk, P., Kiørboe, T (1985). Feeding behaviour and swimming activity of larval herring (Clupea harengus) in relation to density of copepod nauplii. Mar. Ecol. Prog. Ser. 24: $15-21$

Munk, P., Christensen, V., Paulsen, H. (1986). Studies of a larval herring (Clupea harengus L.) patch in the Buchan area. II. Growth, mortality and drift of larvae. Dana 6: $11-24$

Munk, P., Kiørboe, T., Christensen, V (1989). Vertical migrations of herring (Clupea harengus) larvae in relation to light and prey distributions. Environ. Biol. Fish. 26: 87-96

Øiestad, V. (1985). Predation on fish larvae as a regulatory force, illustrated in mesocosm studies with large groups of larvae. NAFO Sci. Coun. Stud. 8: 25-32

Oppenheimer, C. H., Moreira, G. S. (1980). Carbon, nitrogen and phosphorus content in the developmental stages of the brine shrimp Artemia. In: Persoone, G., Sorgeloos, P., Roels, O., Jaspers, E. (eds.) The brine shrimp Artemia, Vol. 2, Physiology, biochemistry, molecular biology. Universa Press. Wettern, Belgium, p. 609-612

Owen, R. W. (1989). Microscale and finescale variations of small plankton in coastal and pelagic environments. J. mar. Res. 47: 197-240

Paffenhöfer, G. A. (1980). Zooplankton distributions as related to summer hydrographic conditions in Onslow Bay, North Carolina. Bull. mar. Sci. 30: 819-832

Paloheimo, J. E., Dickie, L. M. (1966). Food and growth of fishes II. Effects of food and temperature on the relation between metabolism and body size. J. Fish. Res. Bd Can. 23: 869-908

Paranjape, M. A. (1988). Microzooplankton in Lancaster Sound (eastern Canadian Arctic) in summer: biomass and distribution. Deep Sea Res. 35: 1547-1563

Paranjape, M. A., Conover, R. J., Harding, G. C., Prouse, N. J. (1985). Micro- and macrozooplankton on the Nova Scotian Shelf in the prespring bloom period: a comparison of their potential resource utilization. Can. J. Fish. Aquat. Sci. 42: $1484-1492$

Peterman, R. M., Bradford, M. J. (1987). Wind speed and mortality rate of a marine fish, the northern anchovy (Engraulis mordax). Science 235: 354-356

Peters, R. H. (1983). The ecological implications of body size. Cambridge University Press, New York

Peters, R. H., Downing, J. A. (1984). Empirical analysis of zooplankton filtering and feeding rates. Limnol. Oceanogr. 29: 763-784

Peterson, W T., Miller, C. B., Hutchinson, A. (1979). Zonation and maintenance of copepod populations in the Oregon upwelling zone. Deep Sea Res. 26: 467-494

Peterson, W T., Ausubel, S. J. (1984). Diets and selective feeding by larvae of Atlantic mackerel Scomber scombrus on zooplankton. Mar Ecol. Prog. Ser 17: 65-75

Prosser, C. L. (1973). Comparative animal physiology, 3rd edn. Saunders, Philadelphia

Richardson, K., Heath, M. R., Pihl, N. J. (1986). Stucies of a larval herring (Clupea harengus L.) patch in the Buchan area. I. The distribution of larvae in relation to hydrographic features. Dana 6: 1-10

Rombough, P. J. (1988). Respiratory gas exchange, aerobic metabolism, and effects of hypoxia during early life. In: Hoar, W S., Randall, D. J. (eds.) Fish physiology, Vol. XI,
The physiology of developing fish, Part A: eggs and larvae. Academic Press, San Diego, p. 59-161

Rosenthal, H., Hempel, G. (1970). Experimental studies in feeding and food requirements of herring larvae (Clupea harengus L.) In: Steele, J. H. (ed.) Marine food chains. Oliver and Boyd, Edinburgh, p. 344-364

Rothschild, B. J., Osborn, T R. (1988). Small-scale turbulence and plankton contact rates. J. Plankton Res. 10:465-474

SAS Institute Inc. (1985a). SAS/STAT guide for personal computers, Version 6 Edition. Cary, North Carolina

SAS Institute Inc. (1985b). SAS User's Guide: Statistics, Version 5 Edition. Cary, North Carolina. Procedure NLIN, p. $575-606$

Sinclair, M. (1988). Marine populations: an essay on population regulation and speciation. Washington Sea Grant Program, University of Washington Press, Seattle

Smetacek, V. (1981). The annual cycle of protozooplankton in the Kiel Bight. Mar. Biol. 63: 1-11

Smith, S. L., Brink, K. H., Santander, H. Cowles, T. J. Huyer, A. (1981). The effect of advection on variations in zooplankton at a single location near Cabo Nazca, Peru. In: Richards, F. A. (ed.) Coastal \& estuarine sciences I: coastal upwelling. American Geophysical Union, Washington, D.C., p. $400-410$

Stepien, W. P.. Jr (1976). Feeding of laboratory-reared larvae of the sea bream Archosargus rhomboidalis (Sparidae). Mar. Biol. 38: 1-16.

Taggart, C. T., Leggett, W C. (1987). Short-term mortality in post-emergent larval capelin Mallotus villosus II. Importance of food and predator density, and density-independence. Mar. Ecol. Prog. Ser. 41: 219-229

Takahashi, M., Ishizaka, J., Ishimaru, T, Atkinson, L. P., Lee, T. N., Yamaguchi, Y., Fujita, Y., Ichimura, S. (1986). Temporal change in nutrient concentrations and phytoplankton biomass in short time scale local upwelling around the Izu Peninsula, Japan. J. Plankton Res. 8: 1039-1049

Thayer, G. W., Hoss, D. E., Kjelson, M. A., Hettler Jr., W F., Lacroix, M. W. (1974). Biomass of zooplankton in the Newport River Estuary and the influence of postlarval fishes. Chesapeake Sci. 15: 9-16

Theilacker, G. (1987). Feeding ecology and growth energetics of larval northern anchovy, Engraulis mordax. Fish. Bull. U.S. 85: 213-228

Theilacker, G., Dorsey, K. (1980). Larval fish diversity, a summary of laboratory and field research. In: Sharp, G. D. (ed.) Workshop on the effects of environmental variation on the survival of larval pelagic fishes. Intergovernmental Oceanographic Commission Workshop Report No. 28, UNESCO, FAO, Rome p. 106-141

Theilacker, G. H., McMaster, M. F. (1971). Mass culture of the rotifer Brachionus plicatilus and its evaluation as a food for larval anchovies. Mar Biol. 10: 183-188

Thresher, R. E., Harris, G. P., Gunn, S., Clementsen, L. A. (1989). Phytoplankton production pulses and episodic settlement of a temperate marine fish. Nature, Lond. 341 : $641-643$

Tilseth, S., Ellertsen, B. (1984). Food consumption rate and gut evacuation processes of first feeding cod larvae (Gadus morhua L.). In: Dahl, E., Danielssen, D. S., Moksness, E., Solemdal, P. (eds.) The propagation of cod Gadus morhua L. Arendal, Norway. Flodevigen rapportser. 1. 167-183

Tont, S. A. (1981). Temporal variations in diatom abundance off Southern California in relation to surface temperature, air temperature and sea level. J. mar. Res. 39: 191-207

Tucker Jr., J. (1989). Energy utilization in bay anchovy Anchoa mitchilli and black sea bass Centropristis striata eggs and larvae. Fish. Bull. U.S. 87: 279-295 
Vidal, J., Smith, S. L. (1986). Biomass, growth and development of herbivorous zooplankton in the Southeast Bering Sea during spring. Deep Sea Res. 33A: 523-556

Vladimirov, V. I. (1975). Critical periods in the development of fishes. J. Ichthyol. 15: 851-869

von Westernhagen, H., Rosenthal, H. (1979). Laboratory and insitu studies on larval development and swimming performance of Pacific herring Clupea harengus pallasi Helgoländer wiss. Meeresunters. 32: 539-549

Vu, T. T (1983). A histoenzymological study of protease activities in the digestive tract of larvae and adults of sea bass, Dicentrarchus labrax L. Aquaculture 32: 57-69

Walline, P. (1987). Growth and ingestion rates of larval fish populations in the coastal waters of Israel. J. Plankton Res. 9: $91-102$

Ware, D. M. (1975). Growth, metabolism and optimal swimming speed of pelagic fish. J. Fish. Res. Bd Can. 32: 33-41

Werner, R. G., Blaxter, J. H. S. (1981). The effect of prey density on mortality, growth, and food consumption in larval herring (Clupea harengus L.). Rapp. P.-v. Réun. Cons. int. Explor. Mer 178: 405-408

This article was submitted to the editor
Whitledge, T E. (1981). Nitrogen recycling and biological populations in upwelling ecosystems. In: Richards, F. A. (ed.) Coastal and estuarine sciences I: coastal upwelling. American Geophysical Union, Washington, D.C., p. 257-273

Wilkinson, L. (1988). SYSTAT: The system for statistics. SYSTAT, Inc. Evanston, Illinois

Winberg, G. G. (1956). Nauchnye Trudy Belorusskogo Gosudarstvennogo Universiteta imeni V. I. Lenina, Minsk. (Rate of metabolism and food requirements of fishes. Fish. Res. Bd. Canada, Trans, Ser No. 433)

Wroblewski, J. S., Richmann, J. G. (1987). The nonlinear response of plankton to wind mixing events - implications for survival of larval northern anchovy. J. Planktor Res. 9: 103-123

Yin, M. C., Blaxter, J. H. S. (1987). Escape speeds of marine fish larvae during early development and starvation. Mar. Biol. 96: 459-468

Zar, J. H. (1974). Biostatistical analysis. Prentice-Hall, Englewood Cliffs, New Jersey

Manuscript first received: April 3, 1990

Revised version accepted: August 6, 1990 